Prepared in cooperation with the National Park Service

\title{
Towards Automating Measurements and Predictions of Escherichia coli Concentrations in the Cuyahoga River, Cuyahoga Valley National Park, Ohio, 2012-14
}

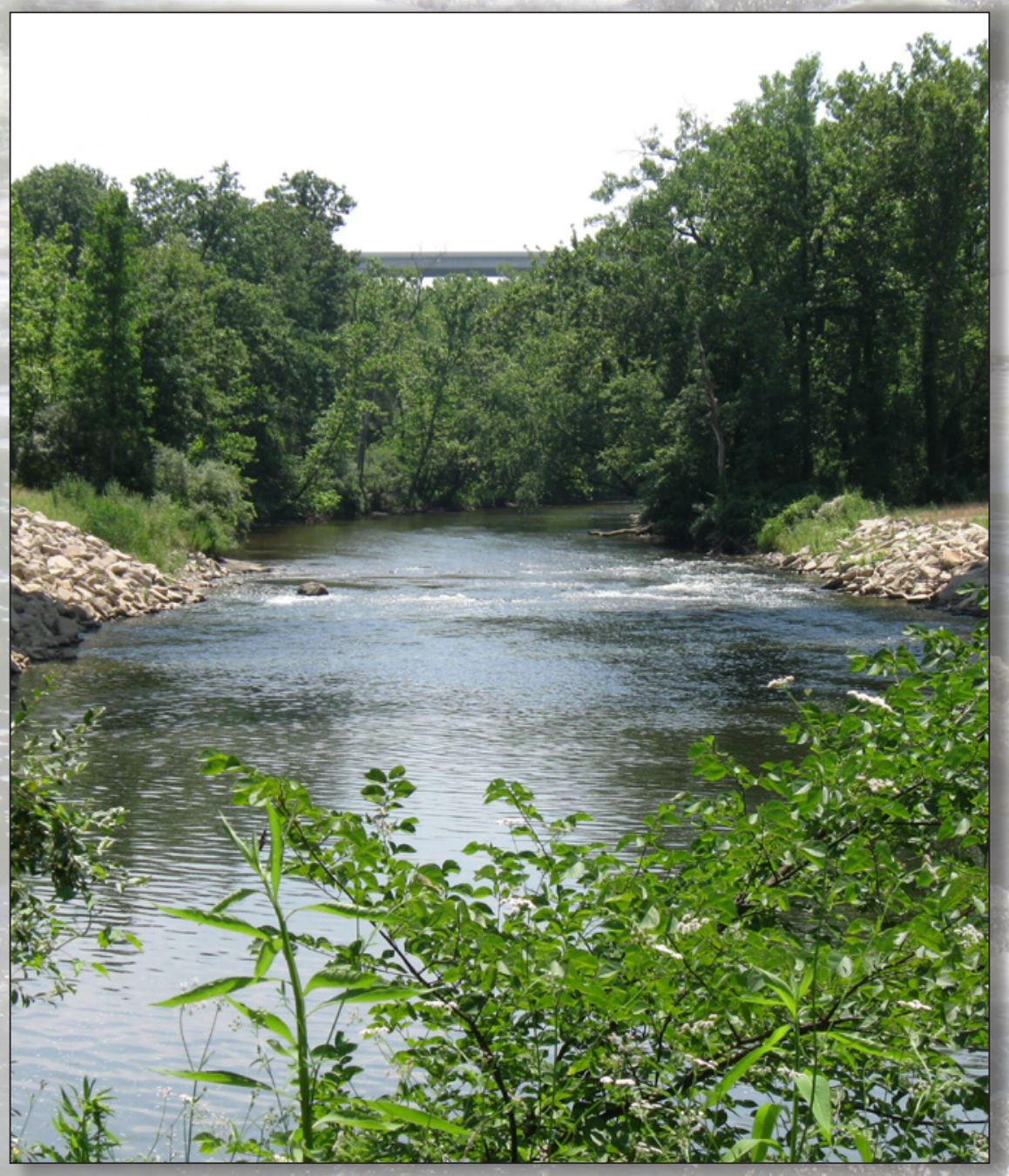

Scientific Investigations Report 2015-5094 
Cover photo. Cuyahoga River at Boston Mills Road, Peninsula, Ohio. (Photograph by Amie Brady, USGS). 


\section{Towards Automating Measurements and Predictions of Escherichia coli Concentrations in the Cuyahoga River, Cuyahoga Valley National Park, Ohio, 2012-14}

By Amie M.G. Brady and Meg B. Plona

Prepared in cooperation with the National Park Service

Scientific Investigations Report 2015-5094 


\title{
U.S. Department of the Interior SALLY JEWELL, Secretary
}

\section{U.S. Geological Survey Suzette M. Kimball, Acting Director}

\author{
U.S. Geological Survey, Reston, Virginia: 2015
}

For more information on the USGS - the Federal source for science about the Earth, its natural and living resources, natural hazards, and the environment—visit http://www.usgs.gov or call 1-888-ASK-USGS.

For an overview of USGS information products, including maps, imagery, and publications, visit http://www.usgs.gov/pubprod/.

Any use of trade, firm, or product names is for descriptive purposes only and does not imply endorsement by the U.S. Government.

Although this information product, for the most part, is in the public domain, it also may contain copyrighted materials as noted in the text. Permission to reproduce copyrighted items must be secured from the copyright owner.

Suggested citation:

Brady, A.M.G., and Plona, M.B., 2015, Towards automating measurements and predictions of Escherichia coliconcentrations in the Cuyahoga River, Cuyahoga Valley National Park, Ohio, 2012-14: U.S. Geological Survey Scientific Investigations Report 2015-5094, 30 p., http://dx.doi.org/10.3133/sir20155094.

ISSN 2328-0328 (online) 


\section{Acknowledgments}

The authors would like to thank the National Park Service seasonal interns Lindsey Steinwachs, Michael Kosmos, and Yeyzy Vargas for their hard work collecting and processing samples. 



\section{Contents}

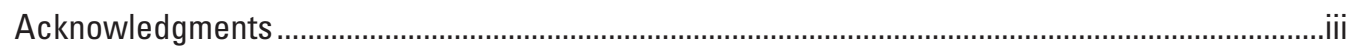

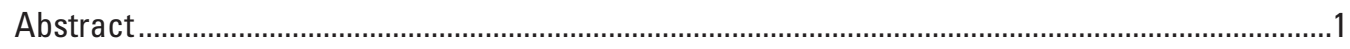

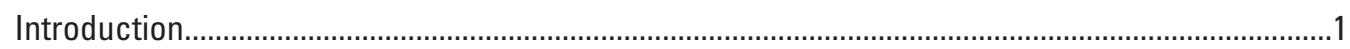

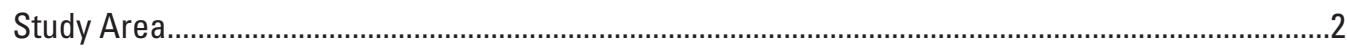

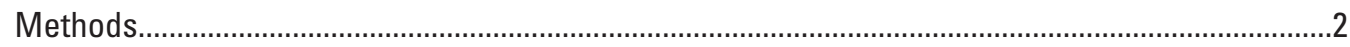

In-Stream Water-Quality and Streamflow Measurements at Jaite ........................................2

Water-Quality Standard for Primary-Contact Recreation.......................................................4

Discrete Sample Collection and Analyses ..........................................................................

Data Compilation From Existing Sources................................................................................

Quality Assurance and Quality Control ..................................................................................

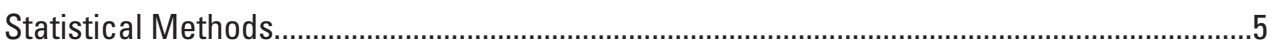

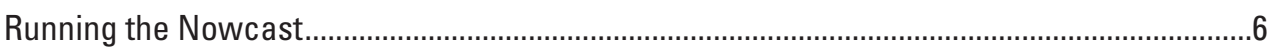

Comparison of Laboratory-Measured and In-Stream Turbidity....................................................

Comparison of Escherichia coli Enumeration Methods.................................................................

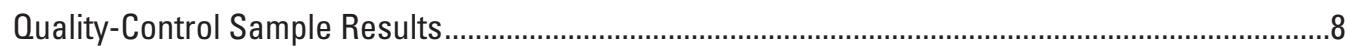

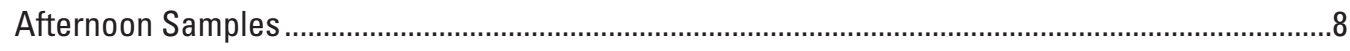

Escherichia coli Concentrations and Environmental and Water-Quality Variables.........................8

Development and Testing of Nowcasts Using Near-Real-Time Data at Jaite................................12

Using Jaite Nowcasts To Predict Water Quality at Lock 29 .........................................................15

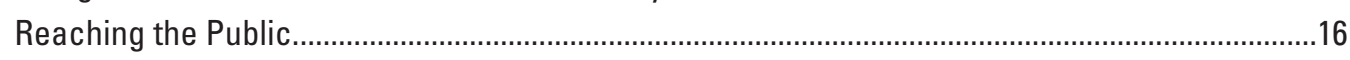

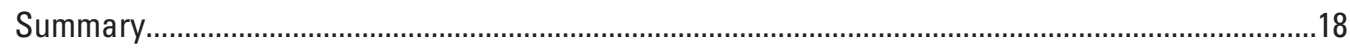

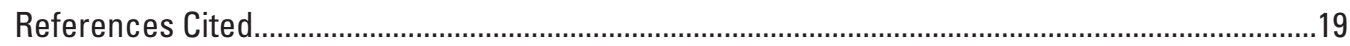

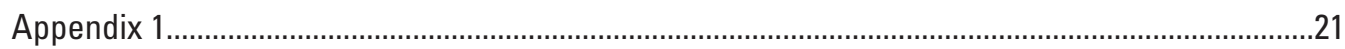

\section{Figures}

1. Map showing Cuyahoga Valley National Park, Ohio, and water-quality sampling sites (U.S. Geological Survey streamgages) for the recreational seasons (May through September) of 2012-14

2. Graph showing the relation between turbidity measured in-stream with a Forest Technology Systems model DTS-12 sensor and turbidity measured in the laboratory with a Hach model 2100P turbidimeter for the Cuyahoga River at Jaite site (U.S. Geological Survey streamgage 04206425) in Cuyahoga Valley National Park, Ohio, May 2012 through August 2012.

3. Graph showing the relation between Escherichia coli (E. coli) concentrations at Cuyahoga Valley National Park, Ohio, as determined by membrane filtration using a modified membrane thermotolerant E. coli (modified mTEC) agar method and the Colilert method for the Cuyahoga River at Jaite site (U.S. Geological Survey streamgage 04206425), May 2012 through September 2014 


\section{Figures-Continued}

4. Graphs showing Echerichia coli (E. coli) concentrations at Cuyahoga Valley National Park, Ohio, as determined by membrane filtration using a modified membrane thermotolerant $E$. coli (modified mTEC) agar method for samples collected in the morning and in the afternoon at the $A$, Cuyahoga River at Jaite (U.S. Geological Survey streamgage 04206425) and B, Cuyahoga River near Lock 29 near Peninsula OH (U.S. Geological Survey streamgage 411433081330000) sites, May 2012 through September 2014 ...

5. Boxplot showing Escherichia coli (E. coli) concentrations in samples collected from the Cuyahoga River at two sites within the Cuyahoga Valley National Park, Ohio, from 2012 to 2014.

6. Scatter plot showing predicted Escherichia coli (E. coli) concentrations from the predictive models compared with measured E. coli concentrations for the Cuyahoga River at Jaite site (U.S. Geological Survey streamgage 04206425) during the recreational seasons (May through September) of 2012-14 in Cuyahoga Valley National Park, Ohio

7. Scatter plot showing predicted Escherichia coli (E. coli) concentrations from the predictive models for the Cuyahoga River at Jaite site (U.S. Geological Survey streamgage 04206425) compared with the measured E. coli concentrations at the Cuyahoga River near Lock 29 near Peninsula OH (U.S. Geological Survey streamgage 411433081330000) site in Cuyahoga Valley National Park, Ohio, during the recreational seasons (May through September) of 2012-14.

8. Graph showing the number of visits to the Cuyahoga River Web page of the Ohio Nowcast Web site (http://www.ohionowcast.info/), by month, from 2012 through 2014

\section{Tables}

1. Results of sample analyses and measured environmental variables at time of sampling at Jaite and Lock 29 sampling sites in Cuyahoga Valley National Park, Ohio, for the recreational seasons (May through September) of 2012 through 2014

2. Pearson's $r$ correlation coefficients between $\log _{10}$-transformed Escherichia coli (E. coli) concentrations as determined by membrane filtration using a modified membrane thermotolerant E. coli ( modified mTEC) agar method and environmental and water-quality variables by recreational season (May through September) from 2012 through 2014.

3. Explanatory variables and regression statistics for models used to predict Escherichia coli (E. coli) concentrations at the Cuyahoga River at Jaite sampling location in Cuyahoga Valley National Park, Ohio.

4. Correct and false positive and negative responses for recreational water-quality conditions using the nowcasts and the persistence model for determining water quality during model development and testing at the Jaite sampling site in Cuyahoga Valley National Park, Ohio

5. Correct and false positive and negative responses for recreational water-quality conditions using the nowcasts at Jaite and the persistence model for determining water quality at Lock 29,

Cuyahoga Valley National Park, Ohio. 


\section{Conversion Factors}

[Inch/Pound to International System of Units]

\begin{tabular}{lcl}
\hline \multicolumn{1}{c}{ Multiply } & By & \multicolumn{1}{c}{ To obtain } \\
\hline inch (in.) & Length & \\
mile (mi) & 2.54 & centimeter $(\mathrm{cm})$ \\
\hline & 1.609 & kilometer $(\mathrm{km})$ \\
\hline square mile $\left(\mathrm{mi}^{2}\right)$ & Area & \\
\hline & 2.590 & square kilometer $\left(\mathrm{km}^{2}\right)$ \\
\hline gallon $(\mathrm{gal})$ & Volume & liter $(\mathrm{L})$ \\
cubic inch $\left(\mathrm{in}^{3}\right)$ & 3.785 & cubic centimeter $\left(\mathrm{cm}^{3}\right)$ \\
\hline & 16.39 & \\
\hline cubic foot per second $\left(\mathrm{ft}^{3} / \mathrm{s}\right)$ & Flow rate & cubic meter per second $\left(\mathrm{m}^{3} / \mathrm{s}\right)$ \\
\hline
\end{tabular}

Temperature in degrees Celsius $\left({ }^{\circ} \mathrm{C}\right)$ may be converted to degrees Fahrenheit $\left({ }^{\circ} \mathrm{F}\right)$ as:

${ }^{\circ} \mathrm{F}=\left(1.8 \times{ }^{\circ} \mathrm{C}\right)+32$.

\section{Supplemental Information}

Bacteria concentrations are given in colony-forming units per 100 milliliters (CFU/100 mL) or most-probable number per 100 milliliters (MPN/100 mL), depending on the method used.

Distance along a river is measured along the course of the river and is reported in river miles.

\section{Abbreviations}

CFU colony-forming unit

CVNP Cuyahoga Valley National Park

E. coli Escherichia coli

FNU formazin nephelometric unit

MPN most-probable number

NTRU nephelometric turbidity ratio unit

NWS National Weather Service

USGS U.S. Geological Survey

WOS water-quality standard 



\title{
Towards Automating Measurements and Predictions of Escherichia coli Concentrations in the Cuyahoga River, Cuyahoga Valley National Park, Ohio, 2012-14
}

\author{
By Amie M.G. Brady ${ }^{1}$ and Meg B. Plona ${ }^{2}$
}

\begin{abstract}
Nowcasts are systems that can provide estimates of the current bacterial water-quality conditions based on predictive models using easily-measured, explanatory variables; nowcasts can provide the public with the information to make informed decisions on the risk associated with recreational activities in natural water bodies. Previous studies on the Cuyahoga River within Cuyahoga Valley National Park (CVNP) have found that predictive models can be used to provide accurate assessments of the recreational water quality. However, in order to run the previously developed nowcasts for CVNP, manual collection and processing of

the samples compared with the measured concentrations. In comparison, the persistence model (using the previous day's sample concentration) correctly predicted concentrations above or below the water-quality standard in only 68 percent of the samples. To determine if the Jaite nowcast could be used for the stretch of the river between Lock 29 and Jaite, the model predictions for Jaite were compared with the measured concentrations at Lock 29. The Jaite nowcast provided correct responses for 77 percent of the Lock 29 samples, which was a greater percentage than the percentage of correct responses (58 percent) from the persistence model at Lock 29.
\end{abstract} samples is required on a daily basis to acquire the required explanatory variable data (laboratory-measured turbidity). The U.S. Geological Survey and the National Park Service collaborated to develop a more automated approach to provide more timely results to park visitors regarding the recreational water quality of the river.

In May 2012, an in-stream water-quality sensor was installed by the U.S. Geological Survey at Jaite, Ohio (a site centrally located in CVNP on the Cuyahoga River), to provide near-real-time measurements of turbidity and water temperature. To transition from methods used during previous studies at CVNP, a relation between laboratory- and in-stream measured turbidity was developed after the recreational season of 2012. During the recreational seasons of 2012 through 2014, discrete water samples were collected and processed to determine Escherichia coli (E. coli) concentrations at Jaite and one site upstream of Jaite (Lock 29) within CVNP. Predictive models, using in-stream turbidity measurements, were developed for the recreational seasons of 2013 and 2014 to estimate recreational water quality in regards to Ohio's single-sample water-quality standard for primary-contact recreation.

A computer program was developed to manage the nowcasts by running the predictive models and posting the results to a publicly accessible Web site daily by 9 a.m. The nowcasts were able to correctly predict $E$. coli concentrations above or below the water-quality standard at Jaite for 79 percent of

\section{Introduction}

Monitoring recreational water quality to determine concentrations of fecal-indicator bacteria can take many forms, from traditional culture-based methods that can take up to 18 hours for results to become available to molecular methods (for example, quantitative polymerase chain reaction, or qPCR) that can be completed within 3 hours. Ultimately, the goal of monitoring is to protect the public from coming into contact with water that contains microorganisms that may cause illness. There are drawbacks to many of the current monitoring and detection methods. Culture-based methods do not provide results in a timely fashion, and molecular methods are not easy to complete, may not work at all locations, and may not be practical for monitoring agencies due to limitations with cost and expertise. Nowcasts are an alternative to culture or molecular methods. Nowcasts are systems that can inform the public of estimates of the bacteriological water-quality conditions in near real time based on predictive models using easily-measured explanatory variables. Predictive models provide predictions of concentrations of fecal-indicator bacteria or probabilities of exceeding a specified water-quality standard (WQS).

\footnotetext{
${ }^{1}$ U.S. Geological Survey.
}

${ }^{2}$ National Park Service. 
Automating Measurements and Predictions of E. coli Concentrations in the Cuyahoga River, Ohio, 2012-14

Elevated concentrations of Escherichia coli (E. coli), a fecal-indicator bacterium, in the Cuyahoga River within Cuyahoga Valley National Park (CVNP; fig. 1) can result in a failure of the water to meet the Ohio single-sample WQS for primary-contact recreational use. Between 2004 and 2011, the WQS was exceeded in more than 50 percent of the samples collected (U. S. Geological Survey, 2015). Sections of the river, including the 22 miles that flow through the park, have been designated by the U.S. Environmental Protection Agency (EPA) as one of the Great Lakes areas of concern because of beneficial-use impairments, including impairments caused by bacterial contamination (Ohio Environmental Protection Agency, 2003). Water-quality concerns have long limited the ability of park managers to promote recreational use of the river within CVNP. The ability to rapidly estimate bacterial levels in the most efficient and cost-effective way would provide the public with information needed to make informed recreational-use decisions about water quality and possibly encourage greater use of the river.

In response to these concerns, the U.S. Geological Survey (USGS) and the National Park Service (NPS) collaborated to develop a method to provide more timely results to park visitors regarding the recreational water quality of the river. In previous research at CVNP, a predictive model based on turbidity measured in the laboratory accurately predicted water-quality conditions at one site on the river more than 80 percent of the time when compared with results of physical samples collected at the same site (in terms of exceedances or nonexceedances of the WQS; Brady and Plona, 2009; Brady and others, 2009). To expand on these capabilities and to decrease demand on staff time for field data collection, a study was initiated to test the use of a continuous in-stream measurement of turbidity for use in a predictive model for recreational water quality. Continuous in-stream measurements of turbidity make it possible for park managers to assess recreational water quality and notify the public from the office without having to visit the site.

This report describes the results of efforts by the USGS and the NPS to improve the operational nowcast at CVNP during the recreational seasons (May through September) of 2012 through 2014. The report describes the procedures used in and results of the (1) acquisition and analysis of the data required to develop the nowcasts (including the transition from laboratory-measured turbidity to in-stream measured turbidity), (2) analysis of results of testing the nowcast, and (3) examination of the feasibility of using the nowcast predictions for a specific reach of the river and (or) for an extended period of time.

\section{Study Area}

The CVNP comprises approximately 33,000 acres along the Cuyahoga River between the cities of Cleveland and Akron in northeastern Ohio (fig. 1). Prior to entering CVNP, the river drains approximately 400 square miles $\left(\mathrm{mi}^{2}\right)$, and another
$300 \mathrm{mi}^{2}$ of drainage area is added before the river leaves the park. In all, 22 miles of the Cuyahoga River and more than 228 miles of tributary streams are within the park boundaries. More than 2.2 million people visit the CVNP annually to enjoy the park's historical, cultural, natural, and recreational activities all in one setting (National Park Service, 2015).

The USGS sampling site at streamgage 411433081330000, Cuyahoga River near Lock 29 near Peninsula Ohio (Lock 29), is along the Ohio and Erie Canal Towpath Trail in Peninsula, Ohio. The Towpath Trail is busy year-round due to its proximity to shops, restaurants, bicycle rentals, and public parking. The USGS streamgage station 04206425, Cuyahoga River at Jaite (Jaite) is approximately 5.3 river miles downstream from Lock 29, near the center of CVNP. The streamgage at Jaite was installed in May 2012 on an abandoned bridge abutment just downstream from the Highland Road bridge. The Cuyahoga River is quickly becoming a popular destination for kayaking as efforts are underway to designate the entire length of the river as a water trail. These two sites bracket one of the most popular stretches of the river for paddling within CVNP.

\section{Methods}

\section{In-Stream Water-Quality and Streamflow Measurements at Jaite}

In May 2012, a water-quality monitor and telemetry instrumentation were added at the Cuyahoga River at Jaite streamgage. The station was equipped with an in-stream Forest Technology Systems Ltd. DTS-12 water-quality sensor that provided continuous measurements of turbidity and temperature. Turbidity and water temperature were recorded every 15 minutes. (The in-stream sensor reports turbidity based on measurements of the forward and back scattered light at a 90-degree $\left({ }^{\circ}\right)$ angle to the light beam; results are reported as formazin nephelometric units). A USGS hydrologic technician visited the site at approximately 2 -week intervals to service the monitor. Except for periods where the monitor was being serviced, data were collected continuously during the recreational season (May through September). The in-stream sensor was removed from the river in early November each year to minimize damage from freezing temperatures as well as to have the instrument recalibrated by the manufacturer. Operation, record computation, and data reporting were done as described in Wagner and others (2006).

Instantaneous streamflow measurements were made periodically, and stream stage was recorded at 15-minute intervals. The stream stage data were used with the instantaneous streamflow measurements to develop stage-discharge rating curves using methods described in Rantz and others (1982a,b). The stage-discharge rating curves were used to compute a time series of streamflows. Near-real-time data were made available through the USGS National Water Information System (NWIS) Web interface (http://waterdata.usgs.gov/oh/nwis) beginning in late April (streamflow) and May 2012 (water quality). 


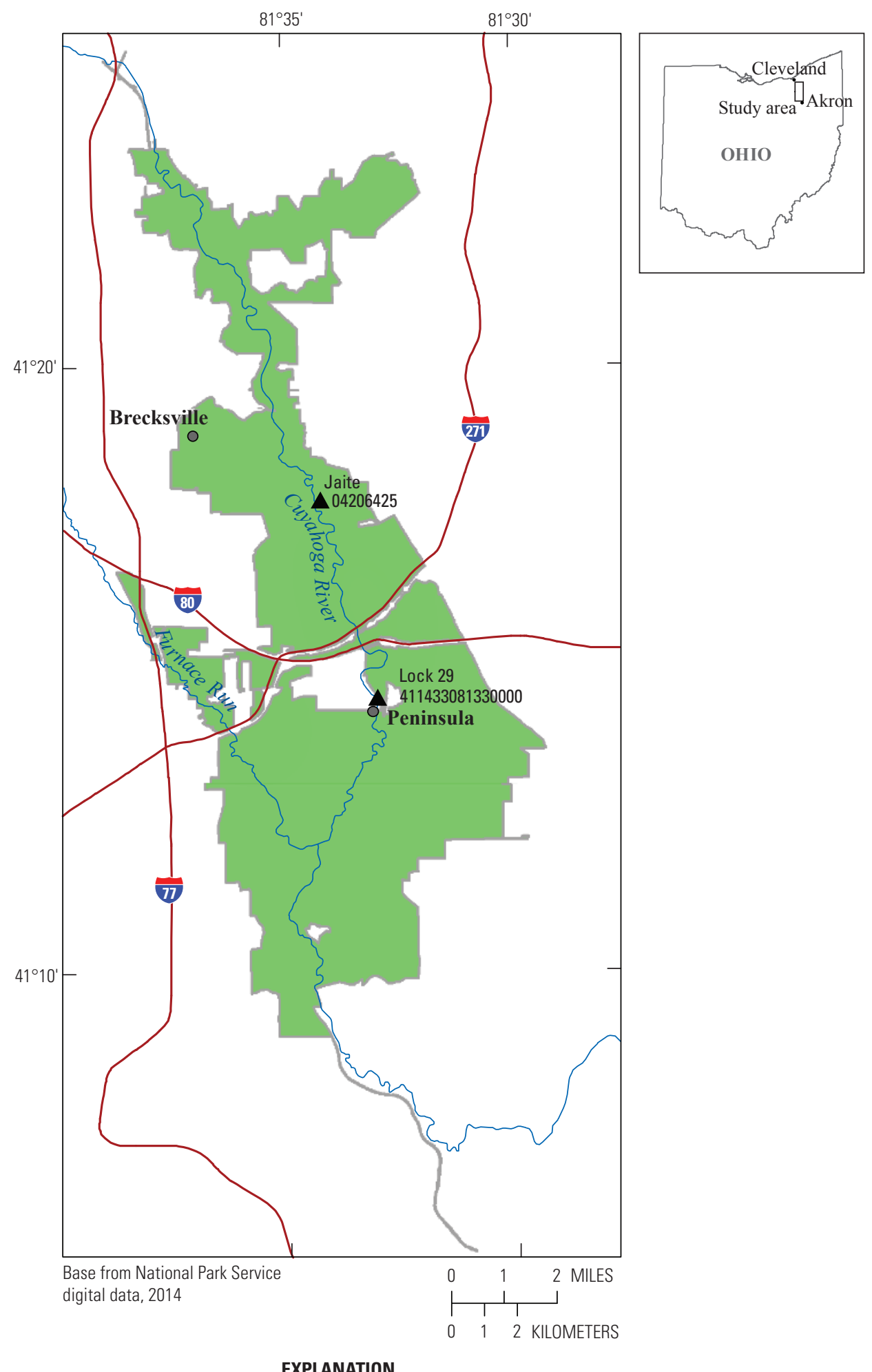

EXPLANATION

Area of park

A Sampling site and number

Figure 1. Cuyahoga Valley National Park, Ohio, and water-quality sampling sites (U.S. Geological Survey streamgages) for the recreational seasons (May through September) of 2012-14. In this study area, the Cuyahoga River generally flows southeast to northwest. 
Automating Measurements and Predictions of E. coli Concentrations in the Cuyahoga River, Ohio, 2012-14

\section{Water-Quality Standard for Primary-Contact Recreation}

The Ohio Environmental Protection Agency assigns minimum water-quality requirements for all state surface waters on the basis of use designations. Within CVNP, the Cuyahoga River has been assigned a Class A use designation of primarycontact recreation, meaning waters that "support, or potentially support, frequent primary contact recreation activities," such as wading, swimming, canoeing and kayaking (Ohio Environmental Protection Agency, 2014). The specific not-toexceed numeric criterion for $E$. coli for this use designation in a single sample is 298 colony-forming units per 100 milliliters (CFU/100 mL). This WQS was used as a benchmark to evaluate recreational water quality in this study.

\section{Discrete Sample Collection and Analyses}

The NPS collected discrete water samples from the Cuyahoga River at both Jaite and Lock 29, one to three times per week during the recreational season. A pedestrian bridge over the river at Lock 29 and the bridge at Highland Road at Jaite were selected as the sampling locations. Samples were collected from a bridge near the center of flow by using a weighted-bottle sampler fitted with a sterile, 1-liter bottle (U.S. Geological Survey, 2006). The weighted sampler was submerged, and the bottle was allowed to fill. To allow for adequate mixing during analysis, sample water was immediately poured off as needed to provide 1 to 2 inches of headspace in the bottle. The bottle was then capped and placed on ice in a cooler until analyses were performed.

Samples collected before 9 a.m. were designated as the morning samples, and E. coli concentrations for these samples were compared with daily nowcast predictions. Several samples were also collected during the afternoon to determine if the morning $E$. coli concentrations were accurately representing the concentrations in the river later in the day. Because visitors to CVNP are engaged in recreational activities throughout the day, nowcast predictions would be most valuable if they provided information for the whole day.

Observations of weather and river condition were noted at the time of sample collection. Water temperature was recorded at Lock 29 using either a digital thermometer $\left( \pm 0.2{ }^{\circ} \mathrm{C}\right)$ or an alcohol thermometer $\left( \pm 0.5^{\circ} \mathrm{C}\right)$ placed in a second sample collected using the weighted sampler so as to not contaminate the primary sample used for bacteria analyses. At Jaite, in-stream turbidity and water temperature was recorded by manually querying the streamgage instrumentation.

Samples were transported to the NPS laboratory, and analyses to determine $E$. coli concentrations were started within 8 hours of sample collection in accordance with compliance requirements for nonpotable waters (Rice and others, 2006). Two methods were used during this study for determining E. coli concentrations - the membrane filtration method using modified membrane thermotolerant $E$. coli (modified
mTEC) agar method (membrane filtration method; U.S. Environmental Protection Agency, 2009) and, starting in August 2013, the Colilert Quanti-Tray/2000 method (Colilert method; IDEXX Laboratories, Inc.). Previous predictive model studies in CVNP used the membrane filtration method to determine E. coli concentrations. Because of its ease-of-use, CVNP personnel were interested in transitioning to the Colilert method from the membrane filtration method. Membrane filtration was used during the entire study to ensure the two tested methods were comparable. For the Colilert method, results are reported as most-probable number per 100 milliliters, and for the membrane filtration method, results are reported as colony-forming units per 100 milliliters.

Turbidity for discrete samples was measured by use of a turbidimeter in the laboratory (Hach Company model 2100P). Previous predictive model studies in CVNP used the laboratory-measured turbidity as an explanatory variable. To transition to using the in-stream turbidity measurements, the laboratory-measured turbidity was measured during the entire study. The turbidimeter used during this study reported turbidity measurements based on a ratio of the signals from its $90^{\circ}$ and transmitted light detectors. Results are reported as nephelometric turbidity ratio units.

\section{Data Compilation From Existing Sources}

Data from existing sources were compiled and used to develop and test predictive models during the study. Throughout the recreational seasons, precipitation data were manually retrieved for the National Weather Service (NWS) AkronFulton International Airport station (National Oceanic and Atmospheric Administration, 2014c) for input into predictive models. At the end of each season, data were retrieved in bulk for the entire season to ensure that the data used for model development for the upcoming season were the final approved data (National Oceanic and Atmospheric Administration, 2014b). To enable a more automated approach to predicting recreation water quality, hourly radar rainfall data were obtained from the NWS (National Oceanic and Atmospheric Administration, 2014a) for a 4-kilometer grid that included the Akron-Fulton International Airport. The sums of the hourly rainfall values for the 24-hour periods prior to $8 \mathrm{a} . \mathrm{m}$. on the day of sampling $\left(R_{d-1}\right)$ and prior to $8 \mathrm{a} . \mathrm{m}$. on the day before sampling $\left(R_{d-2}\right)$ were tallied. Previous research at beaches and at CVNP has shown that weighted rainfall variables may be important explanatory variables in predictive models (Francy and others, 2006; Brady and Plona, 2012; Francy and others, 2013). A weighted 48-hour rainfall variable ( $R W 48$ ) was calculated as shown in equation 1 , which gives more weight to the most recent rainfall.

$$
R W 48=\left(2 \times R_{d-1}\right)+R_{d-2}
$$

All rainfall variables were tallied or calculated for both airport and radar data. 


\section{Quality Assurance and Quality Control}

Use of quality-control and quality-assurance (QA/QC) procedures is important to ensure the integrity of the data being collected. Therefore, strict QA/QC procedures were followed throughout the study. Written protocols were prepared and distributed to all staff prior to the onset of sample collection. The QA/QC procedures for sample collection and analysis of E.coli concentrations followed protocols described in Francy and others (2014) and Myers and others (2014) and were done daily for filter blanks, weekly for replicate samples, and seasonally for field blanks. At least twice during each recreational season, a USGS hydrologist visited the sites and the NPS laboratory to observe the NPS personnel collecting and processing samples to ensure sampling and analytical protocols were being followed properly. Problems identified during these QA/QC checks were minor (for example, calculation and rounding errors), and corrective actions were taken immediately. To quantify sampling and analytical variability for this study, the relative error for each replicate pair was calculated as shown in equation 2 .

$$
\text { Relative error }=\frac{\left|\log _{10}\left(R_{1}\right)-\log _{10}\left(R_{2}\right)\right|}{\frac{\log _{10}\left(R_{1}\right)+\log _{10}\left(R_{2}\right)}{2}} \times 100
$$

where

$$
\begin{aligned}
& R_{1} \quad \begin{array}{l}
\text { is the value of the first replicate sample of the } \\
\text { replicate sample pair; and }
\end{array} \\
& R_{2} \quad \begin{array}{l}
\text { is the value of the second replicate sample of } \\
\text { the replicate sample pair. }
\end{array}
\end{aligned}
$$

Replicate samples were two bottles collected one after the other using the weighted bottle sampler. Turbidity was measured and E. coli concentrations were determined for each bottle.

\section{Statistical Methods}

Exploratory scatter plots and correlation analyses were used to examine the relations between environmental and water-quality variables, including $E$. coli concentrations derived from both membrane filtration and Colilert methods. A linear correlation coefficient (Pearson's $r$ ) was used to determine the degree to which parameters and (or) variables were related to covariates. The Wilcoxon signed-rank test (Wilcoxon, 1945) was used to compare paired groups of data (for example, a comparison between turbidity values measured in the laboratory versus values measured in the stream at the time of sample collection). When comparing two independent groups of data (for example, E. coli concentrations for samples collected at Jaite compared with those for samples collected at Lock 29), the Wilcoxon rank-sum test (Wilcoxon, 1945) was used. When comparing more than two groups of data (for example, E. coli concentrations in samples collected at Jaite during the different sampling years), the Kruskal-Wallis test (Helsel and Hirsch, 2002) was used, followed by a posthoc Dunn's (multiple comparison) test (Dunn, 1964), when applicable. McNemar's test (McNemar, 1947) was used to examine the marginal frequencies of two binary outcomes (for example, this test was used to compare the frequencies of sample results when the two culture methods were discordant in regards to E. coli concentrations above or below the WQS).

To predict $E$. coli concentrations in the river, predictive models were developed and tested annually. The methods used for model development and testing are described in Francy and Darner (2006). For this study, the models were developed using the Virtual Beach 2.4.3 software (U.S. Environmental Protection Agency, 2014). Concentrations of E. coli were $\log _{10}$-transformed before any statistical analyses or modeling was done. Relations between potential explanatory variables (including transformations of explanatory variables) and E. coli concentrations were examined by using Pearson's correlation analysis (Helsel and Hirsch, 2002) and by associated scatterplots. Linear regression methods were used for model development (U.S. Environmental Protection Agency, 2014). Models were selected for testing based on several response statistics of the calibration dataset - accuracy, sensitivity, and specificity (description below). Selected models were tested on an independent year (for example, the model calibrated using data from 2004 to 2011 was tested using data collected in 2012). The level of significance $(\alpha)$ for all statistical tests was set at 0.05 .

Model effectiveness for determining recreational water quality was judged based on several response statistics. Exceedance or nonexceedance of the WQS based on the predicted E. coli concentration for each day was compared with the same based on concentrations as determined with the membrane-filtration method. Rates of correct predictions above and below the WQS (accuracy), as well as rates of false positives and false negatives, were calculated. False positives occur when the model predicts an exceedance of the WQS and the measured concentration was below the WQS (nonexceedance). False negatives occur when the model predicts a nonexceedance of the WQS and the measured concentration was above the WQS (exceedance). Model sensitivity and specificity were also calculated. Sensitivity is the ratio of correctly predicted exceedances of the WQS to the total number of exceedances. Specificity is the ratio of correctly predicted nonexceedances of the WQS to the total number of nonexceedances. These response statistics were used to select models during model development and also to compare predictive models and the persistence model (using the previous day's E. coli concentration to determine the current day's water quality. 


\section{Running the Nowcast}

Predictive models, based mainly on turbidity, were developed for Jaite in previous studies (Brady and Plona, 2009, 2012; Brady and others, 2009). Each year, models were revised and prepared for use during the next recreational season. For the 2012 recreational season, a model was developed by the USGS and run manually by NPS personnel at CVNP. During subsequent years (2013-14), a computer program was set up to run automatically each day at 9 a.m. to (1) retrieve predictor-variable data from NWIS and the NWS, (2) calculate the predicted E. coli concentration for that day, and (3) post results to the Ohio Nowcast Web site (http://www.ohionowcast.info/). The program also sent a daily email to appropriate USGS and NPS staff with the values for the model variables and the predicted E. coli concentration for that day so the model calculations could be checked in Virtual Beach. Confirmation was essential to ensuring the most accurate results were posted to the Web site. Each year, minor glitches, such as rounding errors and incorrect model variables retrieved, were caught early because of the confirmation procedures used.

\section{Comparison of Laboratory-Measured and In-Stream Turbidity}

Turbidity explained the largest proportion of the variation in the predictive models used at CVNP, therefore, it was essential that the parameter was measured and reported consistently and accurately. Because the in-stream sensor used a different technique to measure turbidity than that of the laboratory turbidimeter used during previous research at CVNP, it was necessary to compare the results from the two instruments. The relation between the 2012 measurements was strong $(r=0.97, p<0.0001 ;$ fig. 2). The median for the in-stream sensor measurements was not statistically greater than that for the laboratory turbidimeter (Wilcoxon signed-rank test, $p=0.1752$ ). However, modifications to the models developed using laboratory-measured turbidity were necessary to ensure E. coli concentrations predicted with in-stream sensor measurements were as accurate as possible.

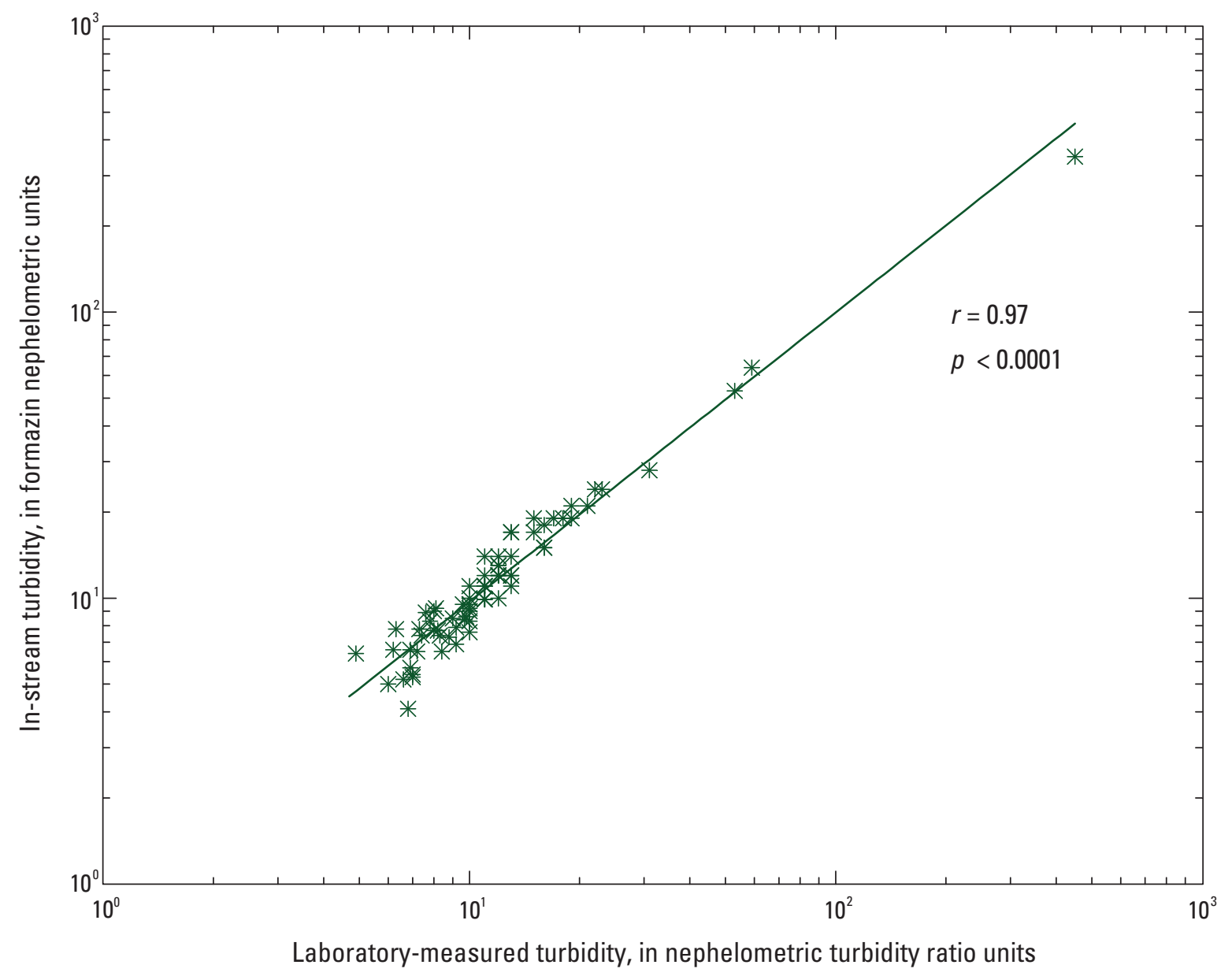

Figure 2. Relation between turbidity measured in-stream with a Forest Technology Systems model DTS-12 sensor and turbidity measured in the laboratory with a Hach model 2100P turbidimeter for the Cuyahoga River at Jaite site (U.S. Geological Survey streamgage 04206425) in Cuyahoga Valley National Park, Ohio, May 2012 through August 2012. $r, 0.97 ; p,<0.0001 ;<$, less than. 
After the recreational season of 2012, an equation was developed to describe the relation between the laboratorymeasured and in-stream measured turbidity (equation 3; assumption of normality was not rejected based on ShapiroWilk test of the residuals). This equation was used to estimate an in-stream turbidity value from turbidity measurements made with the laboratory turbidimeter during previous years (2004-11).

$$
\begin{aligned}
& \log _{10}(\text { in-stream turbidity })=1.01225 \times \\
& \log _{10}(\text { laboratory turbidity })-0.02413
\end{aligned}
$$

The estimated in-stream turbidity values (before 2012) and the in-stream turbidity data (2012 and later) were then used during development of the 2013 and 2014 predictive models.

\section{Comparison of Escherichia coli Enumeration Methods}

In August 2013, the Colilert method for determining E. coli concentrations was added to the study. Compared with the membrane filtration method, the Colilert method requires less hands-on time to complete. The Colilert method was included in this study so that it could ultimately replace the membrane filtration method that historically had been used to test the nowcast predictions. Both enumeration methods are approved for monitoring ambient fresh waterquality by the EPA, and results from previous studies showed that the two methods were highly correlated (Francy and Darner, 2000; Kinzelman and others, 2005). Results similar to those in the previous studies were found during the study described in this report $(r=0.98, p<0.0001$; fig. 3$)$;

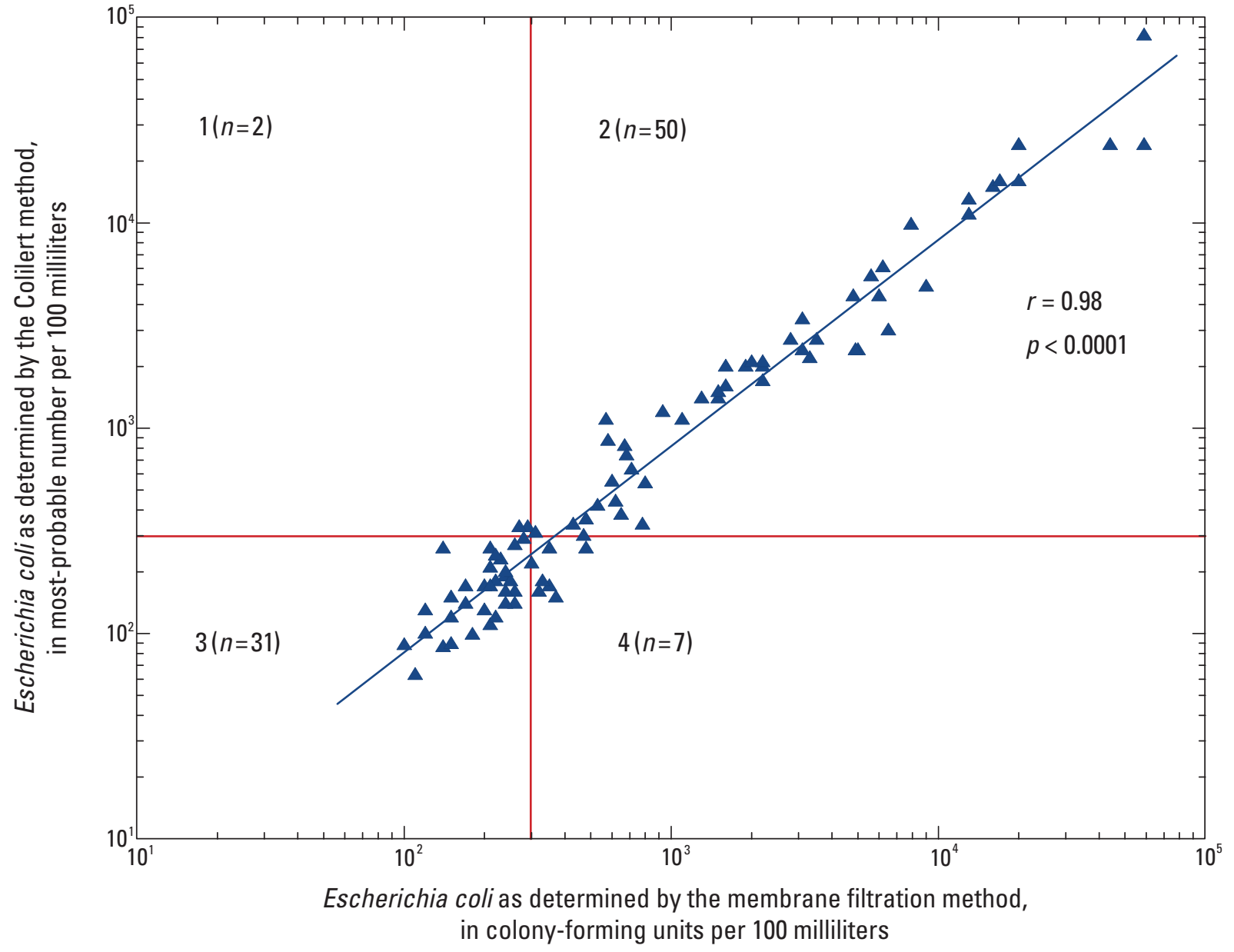

Figure 3. Relation between Escherichia coli (E. coli) concentrations at Cuyahoga Valley National Park, Ohio, as determined by membrane filtration using a modified membrane thermotolerant $E$. coli (modified $\mathrm{mTEC)}$ ) agar method and the Colilert method for the Cuyahoga River at Jaite site (U.S. Geological Survey streamgage 04206425), May 2012 through September 2014. The Ohio single-sample water-quality standard (WOS) of 298 colony-forming units per 100 milliliters is shown on the plot as red lines. The plot was split into quadrants where (1) results from the membrane filtration method were below the WOS but from the Colilert method exceeded the WOS, (2) results from both methods exceeded the WOS, (3) results from both methods were below the WOS, and (4) results from the membrane filtration method exceeded the WOS but from the Colilert method were below the WOS. $n$, number of samples; $r, 0.98 ; p,<0.0001 ;<$, less than. 
however, E. coli concentrations obtained using the membrane filtration method tended to be greater than those obtained using the Colilert method. Upon examination of the data to determine if both methods predicted nonexceedances and exceedances of the WQS, seven of the membrane filtration method results exceeded the WQS when the Colilert method results did not (fig. 3, quadrant 4) and two of the Colilert method results exceeded the WQS when the membrane filtration method results did not (fig. 3, quadrant 1). Based on McNemar's test, the observed discordance between the results of the two methods was not significant $(S=2.78, p=0.0956$ ).

\section{Quality-Control Sample Results}

All filter and field blanks for this study were negative for bacterial growth. For the turbidity replicate sample pairs $(n=41)$, relative errors ranged from 0 to 11 percent. Relative errors for replicate sample pairs processed for $E$. coli by membrane filtration $(n=41)$ ranged from 0 to 14 percent and by the Colilert method $(n=17)$ ranged from 0 to 7.9 percent. This variability is similar to that reported during previous studies at CVNP for bacteriological analyses (0 to 11 percent; Brady and Plona, 2009, 2012; Brady and others, 2009). For E. coli replicate samples with relative errors greater than 10 percent (membrane filtration analyses only), sample concentrations were always less than the WQS. For 9.7 percent of replicate pairs, sample E. coli concentrations as determined using membrane filtration showed disparate results, meaning that the concentration from one replicate sample was above the WQS where that of the other replicate sample was below the WQS. There were no disparate results for replicate samples analyzed using the Colilert method.

\section{Afternoon Samples}

To determine if the morning $E$. coli concentrations were accurately representing concentrations in the river later in the day, afternoon samples were also collected and processed by the membrane filtration method. A total of 58 afternoon samples were collected at Jaite from 2012 to 2014. Compared with the morning samples collected on the same date, there were only eight afternoon samples (14 percent) that did not agree with the morning water-quality condition (concentrations above or below the WQS; fig. 4A), and all eight samples had concentrations that were below the WQS when those of the morning samples were above the WQS. At Lock 29, afternoon samples processed using the membrane filtration method were only collected in 2012 and $2013(n=46)$. Similar to what was observed for samples collected at Jaite, the morning samples tended to have higher concentrations than the afternoon samples (fig. 4B). Six afternoon samples (13 percent) had concentrations that were below the WQS when the associated morning sample concentration was above the WQS.
In terms of protecting the public, the greatest concern would be to not post an advisory when the river water exceeds or is expected to exceed the WQS. Study results did not indicate that the river water-quality conditions worsened from morning to afternoon samples. However, the sampling schedule for afternoon samples was limited and may have excluded dates when storms or other rapidly changing hydrologic conditions altered the water-quality conditions during the day.

\section{Escherichia coli Concentrations and Environmental and Water-Quality Variables}

During the recreational seasons of 2012 through 2014, 196 samples were collected at Jaite, and 162 samples were collected at Lock 29. Summary statistics for E. coli and measured environmental and water-quality variables are listed in table 1. A subset of data that only included samples concurrently collected at both sites was used to compare E. coli, turbidity, and water temperature between the sites. Based on Wilcoxon rank-sum tests, no significant differences in median E. coli concentrations, turbidity, or water temperature were observed between sites. Further, of the 146 sample pairs (concurrent samples collected at Jaite and Lock 29) with E. coli concentration results, only 14 pairs disagreed when comparing if concentrations exceeded the WQS at one site but not the other. This observed discordance was not significant (based on McNemar's test; $S=1.14, p=0.2850$ ).

Radar-indicated rainfall for the 24-hour period prior to 8 a.m. on the day of sampling $\left(\mathrm{R}_{\mathrm{d}-1}\right)$ had a maximum value (that coincided with sample collection) of 2.6 inches observed on July 11, 2013 (data not shown). For this event, only the Lock 29 sample was collected due to closure of the bridge at Jaite. Each consecutive summer (May through September) during this study had more precipitation than the previous summer (based on radar-indicated rainfall) - totals were 12.8 inches in 2012, 20.5 inches in 2013, and 29.7 inches in 2014.

Correlations between $\log _{10}$-transformed E. coli concentrations and square root of $R_{d-2}$ (radar), $\log _{10}$-transformed turbidity, and $\log _{10}$-transformed streamflow were statistically significant at both sites for each year, except square root of $R_{d-2}$ (radar) at Lock 29 for 2014, possibly due to the small sample size (table 2). Correlations between these variables were also statistically significant by site when all data for the study were combined. Correlations between E. coli and water temperature were not statistically significant at either site for any year or all three years combined.

Median concentrations of $E$. coli (fig. 5) increased during each year of this study. Similar to radar rainfall data, monthly mean streamflow data indicated that streamflows during summers 2013 and 2014 were greater than those during summer 2012. Increased rainfall and subsequent increased streamflows 


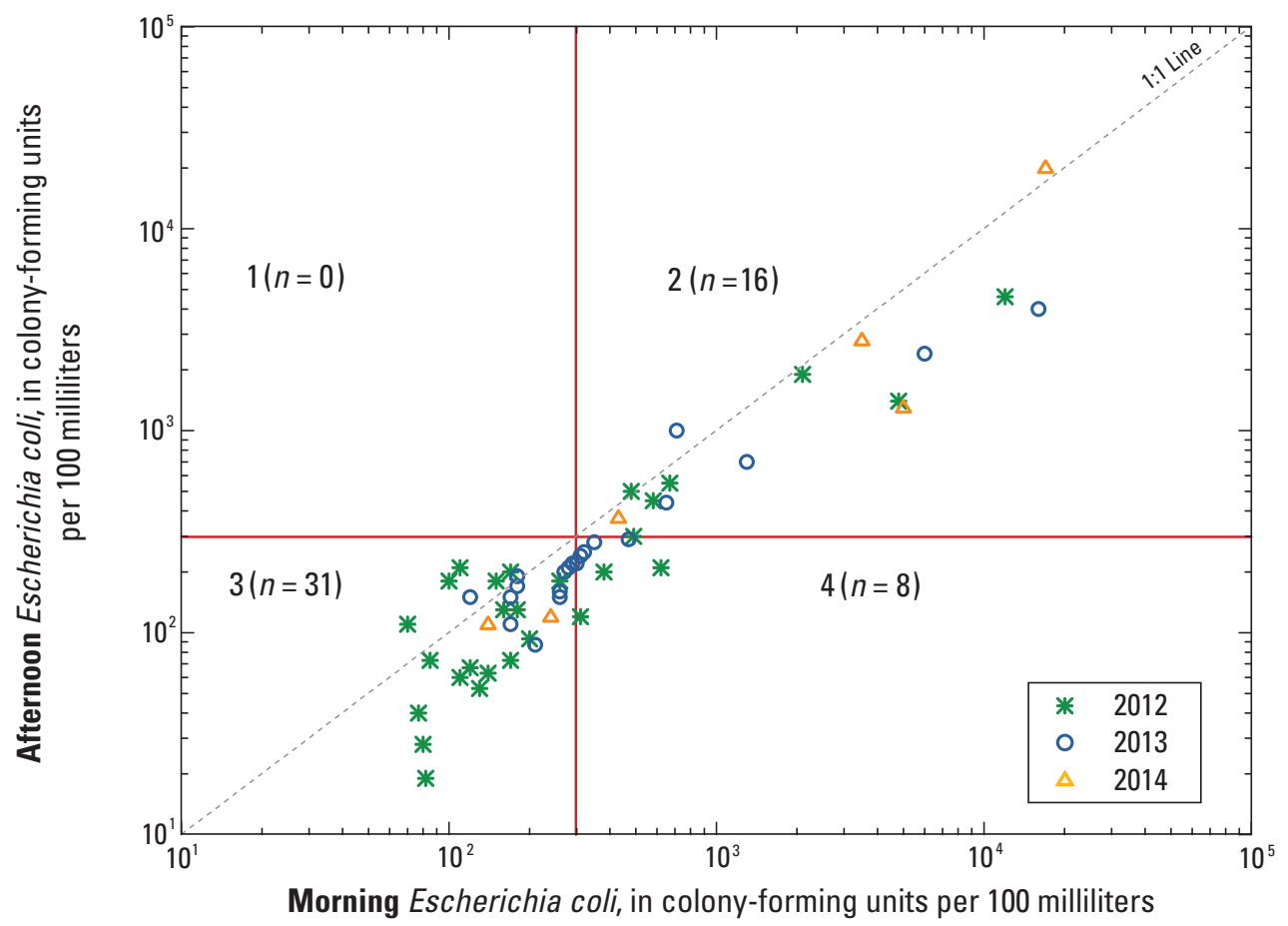

B

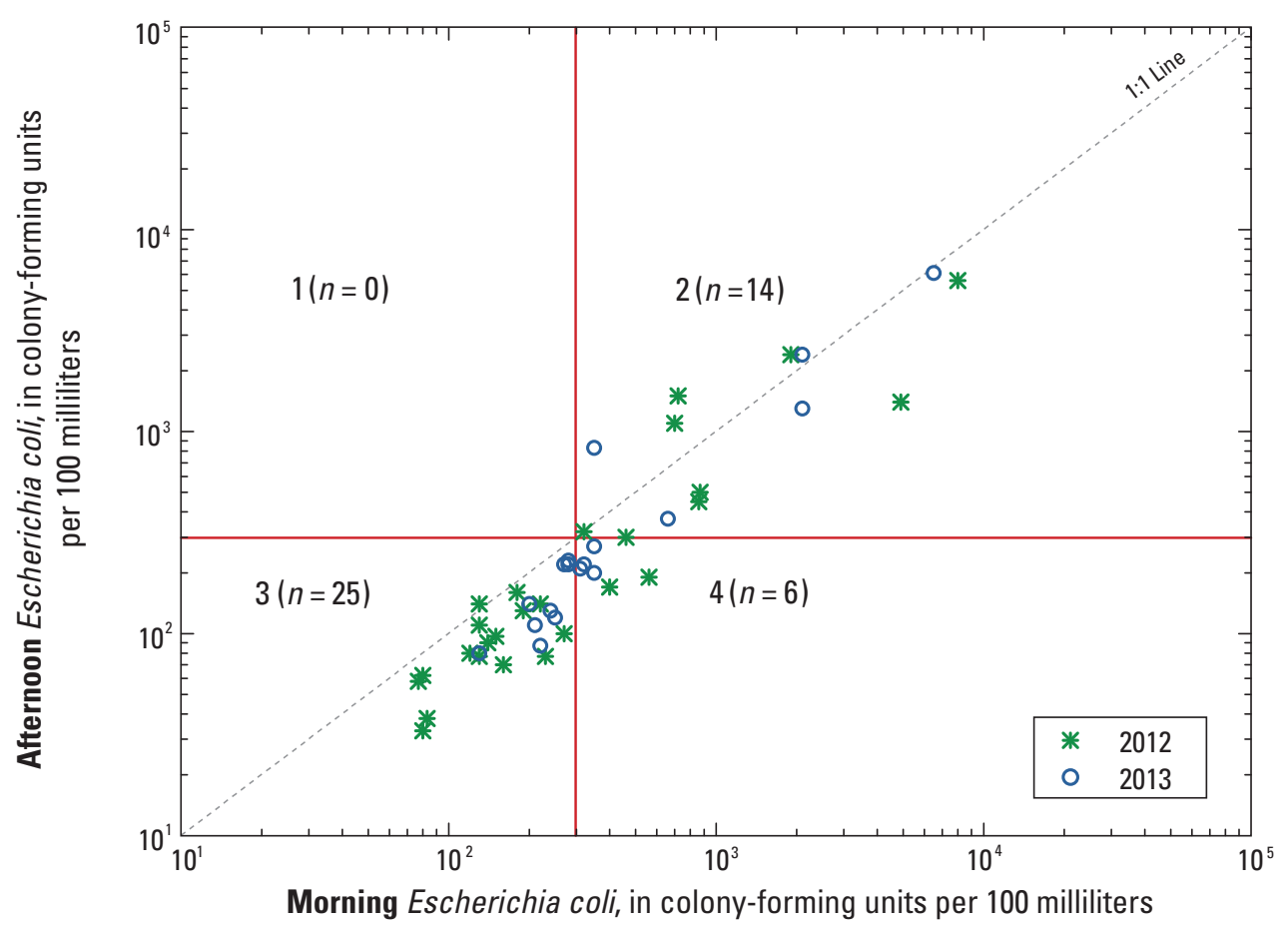

Figure 4. Escherichia coli (E. coli) concentrations at Cuyahoga Valley National Park, Ohio, as determined by membrane filtration using a modified membrane thermotolerant $E$. coli (modified mTEC) agar method for samples collected in the morning and in the afternoon at the $A$, Cuyahoga River at Jaite (U.S. Geological Survey streamgage 04206425) and B, Cuyahoga River near Lock 29 near Peninsula OH (U.S. Geological Survey streamgage 411433081330000) sites, May 2012 through September 2014. The Ohio single-sample water-quality standard (WOS) of 298 colony-forming units per 100 milliliters is shown on the plot as red lines. The plot was split into quadrants where (1) results from morning samples were below the WOS but from afternoon samples exceeded the WOS, (2) results from both samples exceeded the WOS, (3) results from both samples were below the WOS, and (4) results from morning samples exceeded the WOS but from afternoon samples were below the WOS. $n$, number of samples. 
Table 1. Results of sample analyses and measured environmental variables at time of sampling at Jaite and Lock 29 sampling sites in Cuyahoga Valley National Park, Ohio, for the recreational seasons (May through September) of 2012 through 2014.

[Reported streamflow is the instantaneous streamflow at 8 a.m. or 1 p.m. associated with morning or afternoon samples, respectively. A turbidity value was considered an estimate when the sample had to be diluted to read within the instrument's operational range. CFU/100 mL, colony-forming units per $100 \mathrm{mil}$ liliters; MPN/100 mL, most probable number per 100 milliliters; NTRU, nephelometric turbidity ratio units; FNU, formazin nephelometric units; f ${ }^{3} / \mathrm{s}$, cubic feet per second; E, estimated value]

\begin{tabular}{|c|c|c|c|c|c|}
\hline Variable & $\begin{array}{l}\text { Number of } \\
\text { samples }\end{array}$ & Minimum & Median & Maximum & Mean \\
\hline \multicolumn{6}{|c|}{ Lock 29} \\
\hline Escherichia coli, in CFU/100 mL & 150 & 33 & 300 & 44,000 & 2,200 \\
\hline Escherichia coli, in MPN/100 mL & 35 & 88 & 1,000 & 24,000 & 2,700 \\
\hline Turbidity, in NTRU & 162 & 2.9 & 12 & 1,500 & 47 \\
\hline Water temperature, in degrees Celsius & 162 & 16.0 & 21.5 & 24.5 & 21.2 \\
\hline \multicolumn{6}{|c|}{ Jaite } \\
\hline Escherichia coli, in CFU/100 mL & 179 & 19 & 260 & 78,000 & 2,800 \\
\hline Escherichia coli, in MPN/100 mL & 82 & 63 & 340 & 82,000 & 3,300 \\
\hline Turbidity, in NTRU & 196 & 4.0 & 13 & $\mathrm{E} 1,900$ & 63 \\
\hline Turbidity, in FNU & 196 & 3.4 & 14 & $\mathrm{E} 1,600$ & 63 \\
\hline Water temperature, in degrees Celsius & 196 & 15.9 & 21.4 & 25.9 & 21.3 \\
\hline Instantaneous streamflow, in $\mathrm{ft}^{3} / \mathrm{s}$ & 186 & 131 & 366 & 4,490 & 557 \\
\hline
\end{tabular}

Table 2. Pearson's $r$ correlation coefficients between $\log _{10}$-transformed Escherichia coli (E. coli) concentrations as determined by membrane filtration using a modified membrane thermotolerant $E$. coli ( modified $\mathrm{mTEC}$ ) agar method and environmental and waterquality variables by recreational season (May through September) from 2012 through 2014.

[Relations significant at $\alpha=0.05$ are indicated in bold. The number of samples for each relation is indicated in parentheses. $\mathrm{R}_{\mathrm{d}-2}$ (radar) is the sum of the hourly totals for radar rain for the 24 hours prior to 8 a.m. on the day prior to the day of sampling. NTRU, nephelometric turbidity ratio units; FNU, formazin nephelometric units; $\mathrm{ft}^{3} / \mathrm{s}$, cubic feet per second; --, no data available]

\begin{tabular}{|c|c|c|c|c|c|}
\hline Year & $\begin{array}{l}\text { Square root of } \mathbf{R}_{\mathrm{d}-2} \\
\text { (radar), in inches }\end{array}$ & $\begin{array}{l}\text { Log }_{10} \text { turbidity, } \\
\text { in NTRU }\end{array}$ & $\begin{array}{l}\log _{10} \text { turbidity, } \\
\text { in FNU }\end{array}$ & $\begin{array}{l}\log _{10} \text { streamflow, } \\
\text { in } \mathrm{ft}^{3} / \mathrm{s}\end{array}$ & $\begin{array}{l}\text { Water temperature, } \\
\text { in degrees Celsius }\end{array}$ \\
\hline \multicolumn{6}{|c|}{ Jaite } \\
\hline 2012 & $0.35(66)$ & $\mathbf{0 . 8 6}(66)$ & $\mathbf{0 . 8 8}(66)$ & $\mathbf{0 . 8 8}(60)$ & $-0.057(66)$ \\
\hline 2013 & $\mathbf{0 . 3 7}(67)$ & $0.92(68)$ & $0.93(68)$ & $\mathbf{0 . 8 7}(65)$ & $0.063(68)$ \\
\hline 2014 & 0.35 (45) & 0.90 (45) & $0.91(45)$ & 0.77 (45) & $-0.12(45)$ \\
\hline 2012-2014 & $\mathbf{0 . 4 0}(178)$ & $\mathbf{0 . 8 8}(179)$ & $\mathbf{0 . 8 8}(179)$ & $\mathbf{0 . 7 6}(170)$ & $-0.11(179)$ \\
\hline \multicolumn{6}{|c|}{ Lock 29} \\
\hline 2012 & 0.29 (63) & 0.75 (63) & -- & $\mathbf{0 . 8 3}(57)$ & $-0.082(63)$ \\
\hline 2013 & 0.45 (63) & 0.91 (64) & -- & 0.86 (61) & $0.030(64)$ \\
\hline 2014 & $0.38(23)$ & 0.88 (23) & -- & $0.72(23)$ & $0.0022(23)$ \\
\hline 2012-2014 & $\mathbf{0 . 4 2}(149)$ & $\mathbf{0 . 8 4}(150)$ & -- & $\mathbf{0 . 7 5}(141)$ & $-0.046(150)$ \\
\hline
\end{tabular}




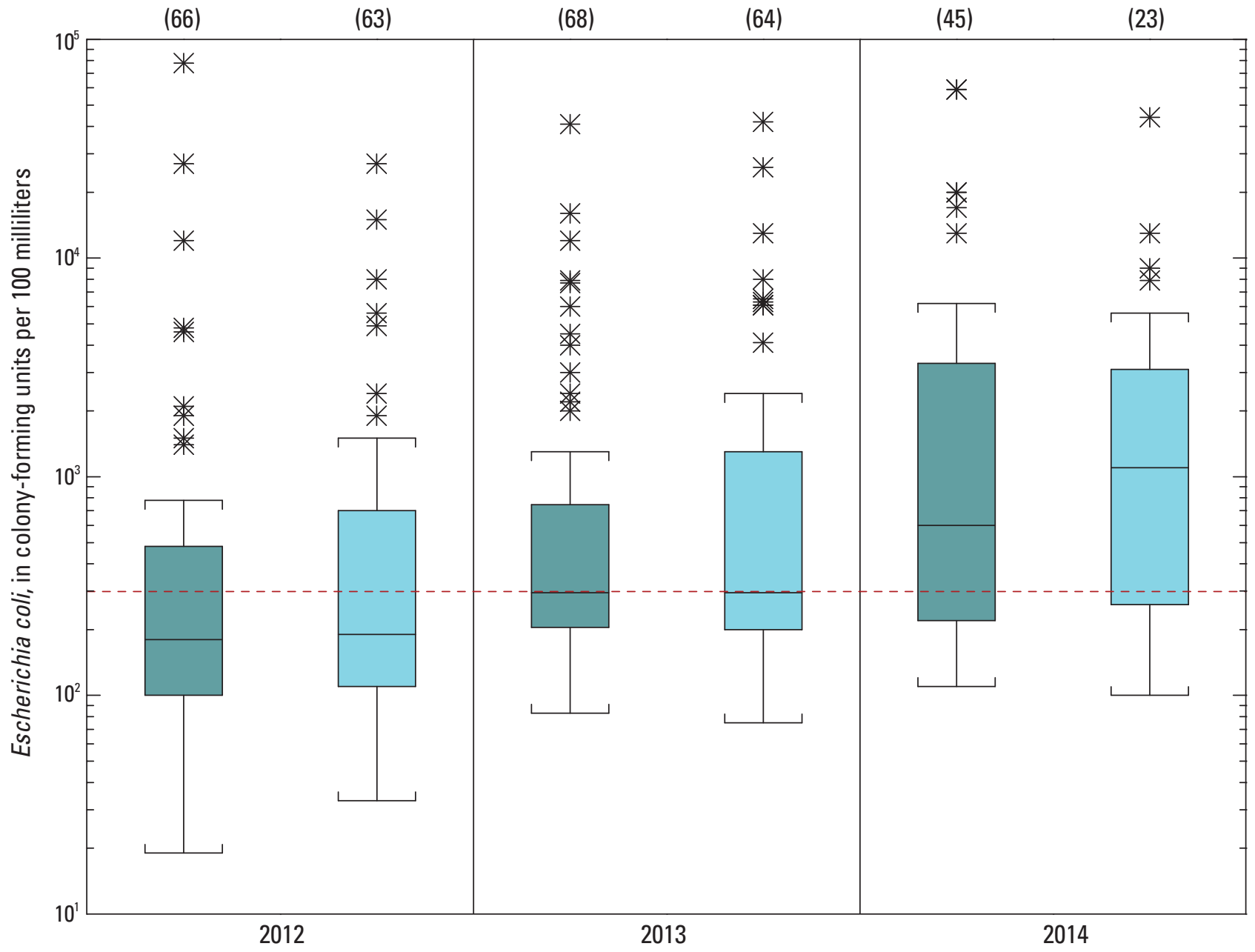

Figure 5. Escherichia coli (E. coli) concentrations in samples collected from the Cuyahoga River at two sites within the Cuyahoga Valley National Park, Ohio, from 2012 to 2014. The Ohio single-sample water-quality standard (W0S) of 298 colony-forming units per 100 milliliters is shown on the plot as a red line. During the 2013 season, the median concentrations for both sites are just below the WOS.

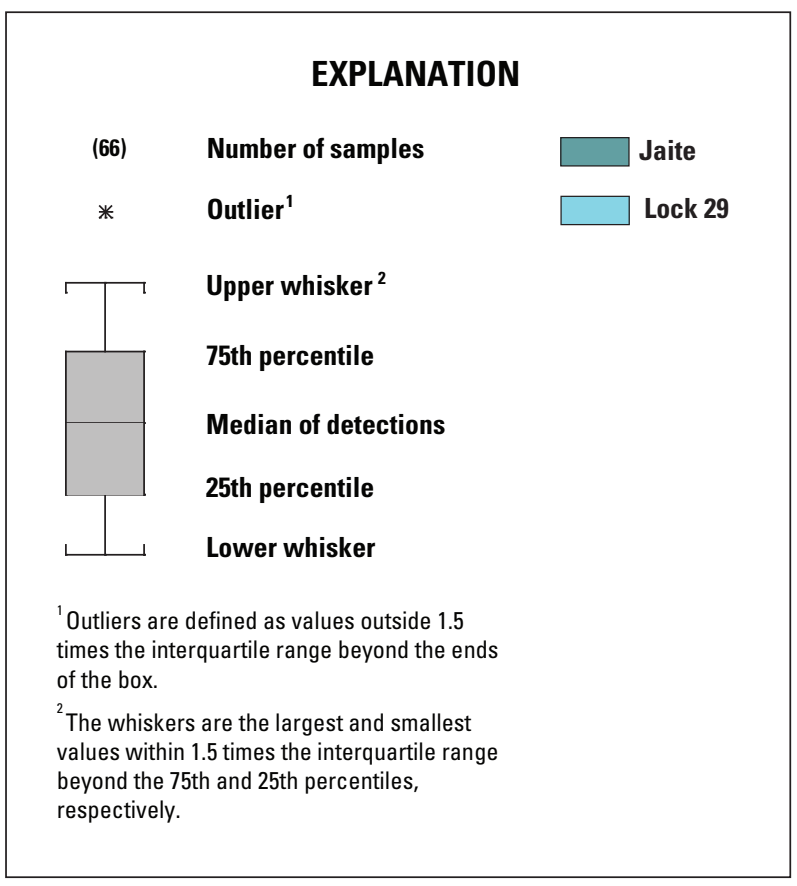


may explain some of the observed increase in median $E$. coli concentrations each year (fig. 5). Other changes in the watershed, including removal of upstream dams or alterations to wastewater management practices, could also affect concentrations of $E$. coli in the river. A Kruskal-Wallis test followed by a post-hoc Dunn's test showed that median E. coli concentrations in 2013 and 2014 were statistically larger than the median E. coli concentration in 2012 for both sites.

\section{Development and Testing of Nowcasts Using Near-Real-Time Data at Jaite}

Prior to each recreational season, predictive models were developed for use in a nowcast at Jaite (table 3). The variables chosen for each year's model always included turbidity and a rainfall variable. A radar rainfall variable was used as an alternative variable to the NWS airport weather station-acquired rainfall data starting in 2013 because the radar rainfall data were in electronic format readily available for use by the computer program used to make daily predictions. Radar data were not available prior to 2008; therefore, the models for 2013 and
2014 were calibrated using data starting in 2008. For the 2014 model, the day of the year was added even though it was not statistically significant because the resulting percentage of correct responses for this model was greater than that for a model that did not include this variable (data not shown). Alternate models were created for use during 2013 and 2014 in case the radar rainfall data were not available; however, only the 2014 alternate model was used (table 3).

During 2012, the nowcast was run manually by NPS personnel because the relation between the two instruments used to measure turbidity was not yet available. Starting in 2013, the nowcast was run automatically using the computer program as described in the "Running the Nowcast" section. Results were posted to the Ohio Nowcast Web site by 9 a.m. each morning. The predicted $E$. coli concentrations were double-checked manually. Morning and afternoon samples were collected to compare E. coli results (membrane filtration method only) with the morning predictions from the predictive models ( $n=120$ for morning samples and $n=57$ for afternoons samples). All predictions and corresponding measured $E$. coli concentrations (when applicable) are listed in appendix 1 .

Table 3. Explanatory variables and regression statistics for models used to predict Escherichia coli concentrations at the Cuyahoga River at Jaite sampling location in Cuyahoga Valley National Park, Ohio.

[The type of instrument used to measure turbidity and the source of rainfall data are indicated in parentheses. The 2014 alternate model was used only when radar rainfall information was not available. $\mathrm{R}^{2}$, fraction of the variation in Escherichia coli concentrations that is explained by the model; RMSE, root mean square error; RW48, rainfall weighted for 48 -hour period prior to sampling; $\mathrm{R}_{\mathrm{d}-2}$, sum of the hourly rainfall values for the 24 -hour period prior to 8 a.m. on the day prior to sampling; $<$, less than]

\begin{tabular}{|c|c|c|c|c|c|c|}
\hline Test year & $\begin{array}{l}\text { Calibration data } \\
\text { seasons } \\
\text { (number of } \\
\text { samples) }\end{array}$ & $\begin{array}{c}\text { Adjusted } \\
\mathbf{R}^{2}\end{array}$ & RMSE & Model parameter & $\begin{array}{l}\text { Parameter } \\
\text { estimate }\end{array}$ & $p$-value \\
\hline \multirow{2}{*}{2012} & \multirow{2}{*}{$\begin{array}{c}2004-2011 \\
\quad(373)\end{array}$} & \multirow{2}{*}{0.77} & \multirow{2}{*}{0.2999} & $\log _{10}$ turbidity (laboratory) & 0.809 & $<0.0001$ \\
\hline & & & & Square root of RW48 (airport) & 0.507 & $<0.0001$ \\
\hline \multirow{2}{*}{2013} & \multirow{2}{*}{$\begin{array}{l}2008-2012 \\
\quad(229)\end{array}$} & \multirow{2}{*}{0.74} & \multirow{2}{*}{0.3294} & $\log _{10}$ turbidity (in-stream) & 1.128 & $<0.0001$ \\
\hline & & & & Square root of $\mathrm{R}_{\mathrm{d}-2}$ (radar) & 0.632 & $<0.0001$ \\
\hline \multirow[t]{2}{*}{2014} & \multirow{2}{*}{$\begin{array}{l}2008-2013 \\
\quad(292)\end{array}$} & \multirow[t]{2}{*}{0.77} & \multirow[t]{2}{*}{0.3107} & $y$-intercept & 1.341 & $<0.0001$ \\
\hline & & & & $\log _{10}$ turbidity (in-stream) & 1.122 & $<0.0001$ \\
\hline \multirow{3}{*}{$\begin{array}{l}2014 \\
\quad \text { (alternate) }\end{array}$} & \multirow{3}{*}{$\begin{array}{l}2008-2013 \\
\quad(292)\end{array}$} & \multirow{3}{*}{0.75} & \multirow{3}{*}{0.3197} & $\log _{10}$ turbidity (in-stream) & 1.080 & $<0.0001$ \\
\hline & & & & RW48 (airport) & 0.1770 & $<0.0001$ \\
\hline & & & & Day of the year & -0.00092 & 0.1299 \\
\hline
\end{tabular}


Model predictions during testing were compared with available measured E. coli concentrations (fig. 6). Almost 47 percent of the samples collected at Jaite during this study exceeded the WQS. The nowcasts correctly predicted 79.1 percent of samples above or below the WQS. There were more false positives during 2013 than for the other years, but the percentages of false positives were similar for 2013 and 2014. Conversely, there was a decrease in the percentage of false negatives observed each season with the greatest percentage observed during the 2012 season (11 percent) and the lowest observed during the 2014 season ( 0 percent). The observed changes in the percentages of false positives and false negatives may not be indicative of any improvements in the models, but may be due to the tendency of the models to overpredict E. coli concentrations (fig. 6) in conjunction with the increased number of exceedances each year (that is, there is a greater probability of predicting an exceedance if there are more exceedances).
Response statistics varied slightly from year to year (table 4), but the predictive models were more effective at correctly predicting $E$. coli concentrations above or below the WQS than the persistence model. During model development, the predictive models always performed better than the persistence model in terms of percent correct responses, sensitivity, and specificity. During model testing, for all years, the percentages of correct responses for the predictive models were greater than that for the persistence model. Specificity for the predictive models during testing decreased each year and was less than the persistence model during 2013 and 2014. However, sensitivity for the predictive models during testing was always higher than that for the persistence model and showed an increase each year. Overall (looking at all 3 years of this study), the predictive models performed better than the persistence model, correctly predicting 89 percent of the exceedances and 70 percent of the nonexceedances of the WQS.

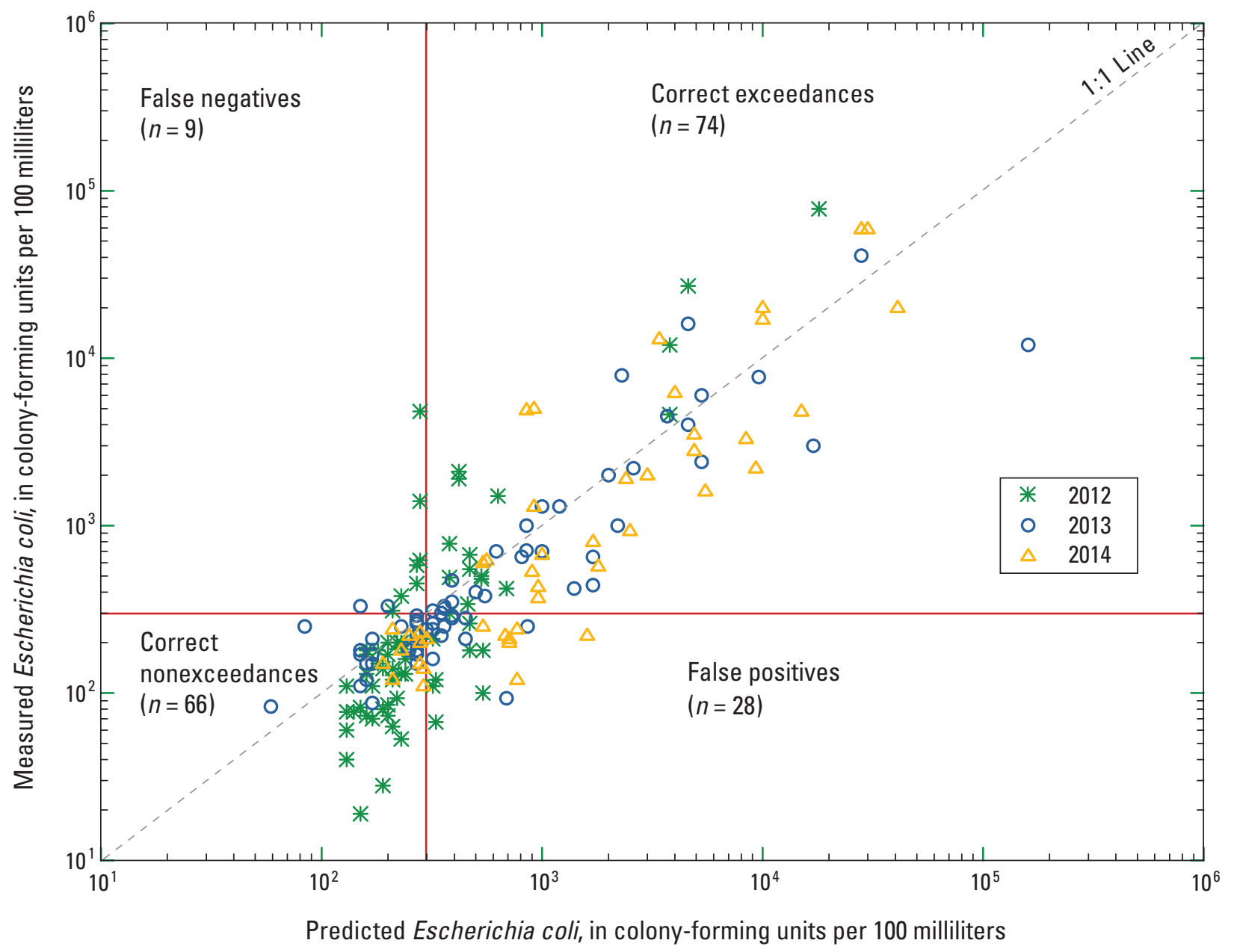

Figure 6. Predicted Escherichia coli (E. coli) concentrations from the predictive models compared with measured E. coli concentrations for the Cuyahoga River at Jaite site (U.S. Geological Survey streamgage 04206425) during the recreational seasons (May through September) of 2012-14 in Cuyahoga Valley National Park, Ohio. The Ohio single-sample water-quality standard of 298 colony-forming units per 100 milliliters is shown on the plot as red lines. $n$, number of samples. 


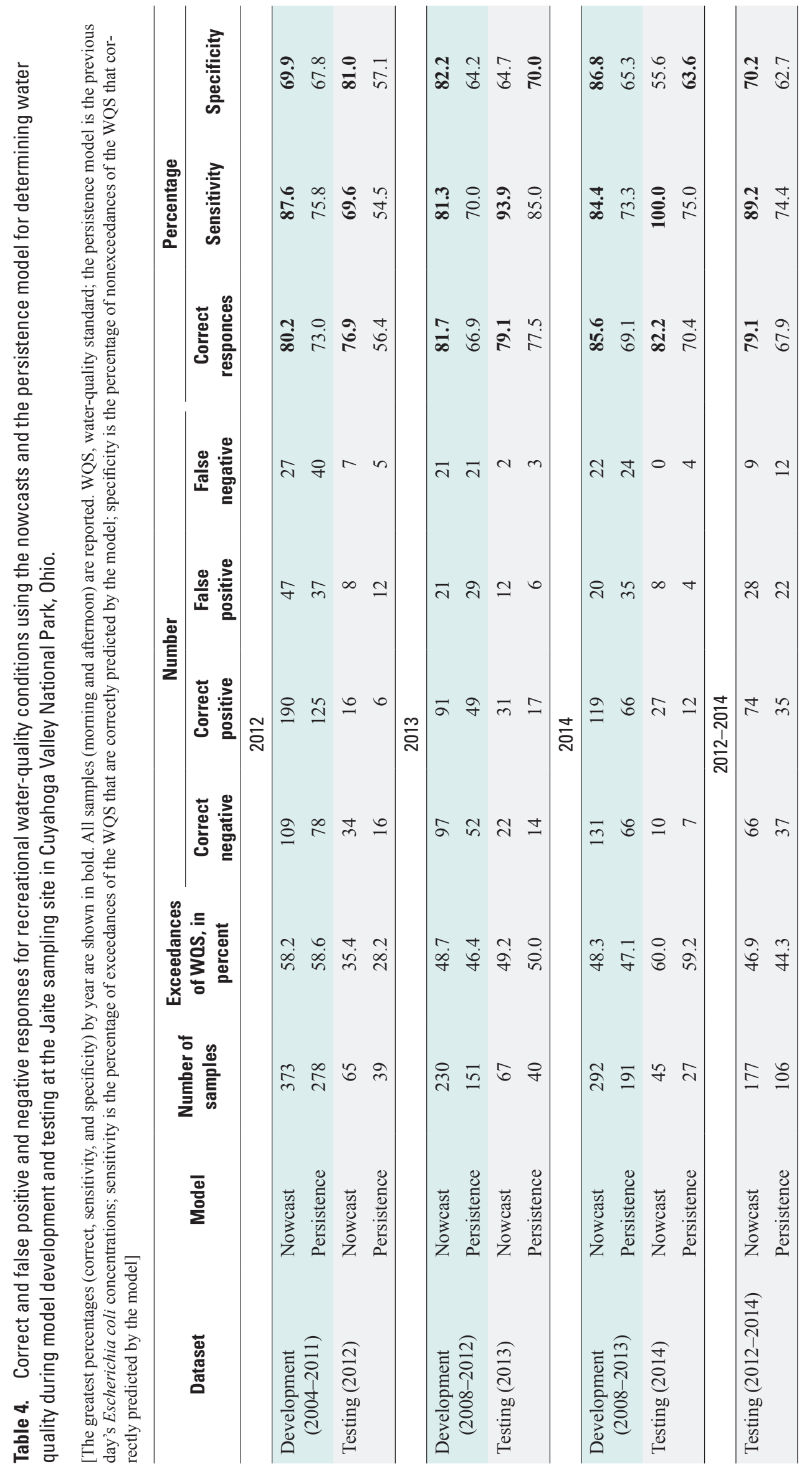




\section{Using Jaite Nowcasts To Predict Water Quality at Lock 29}

Comparison of E. coli concentrations (membrane filtration method only) in samples collected at Lock 29 with those collected at Jaite showed some variations in concentrations, but there were no significant differences in median concentrations between the sites or when examining if concentrations exceeded the WQS at one site but not the other. Brady and others (2009) showed that the predictive models for the CVNP have a limited ability to accurately predict concentrations at upstream locations. However, the nearest upstream site in Brady and others (2009) is more than 14 river miles upstream from Jaite whereas Lock 29 is 5.3 river miles upstream. Given that the sample concentrations at Lock 29 and Jaite did not differ markedly, that the sites are physically close, and that the Jaite nowcasts performed well at determining water-quality conditions at Jaite, the model predictions were used to determine whether the Jaite nowcasts could predict water-quality conditions at Lock 29.
A total of 148 samples were collected at Lock 29 for times when a model prediction was also available at Jaite (fig. 7). Of these samples, 50.7 percent exceeded the WQS. The 2013 predictive model tended to overpredict $E$. coli concentrations at Lock 29 compared with the other years, and therefore, the percentage of false positives was higher during 2013 than for the other years. Similar to what was observed for Jaite, there was a decrease in the percentage of false negatives observed each season at Lock 29. For all years, the Jaite predictive models correctly predicted 77 percent of the Lock 29 samples above or below the WQS with a sensitivity of 82.7 percent and a specificity of 71.2 percent (table 5). In comparison, the persistence model predicted only 57.8 percent of the samples correctly. During each year, the Jaite nowcasts predicted water-quality conditions at Lock 29 better than the persistence model based on samples collected at Lock 29. Predictive model response statistics were similar between the two sites, implying that the Jaite nowcasts could be used to predict $E$. coli concentrations for the stretch of the river between Lock 29 and Jaite.

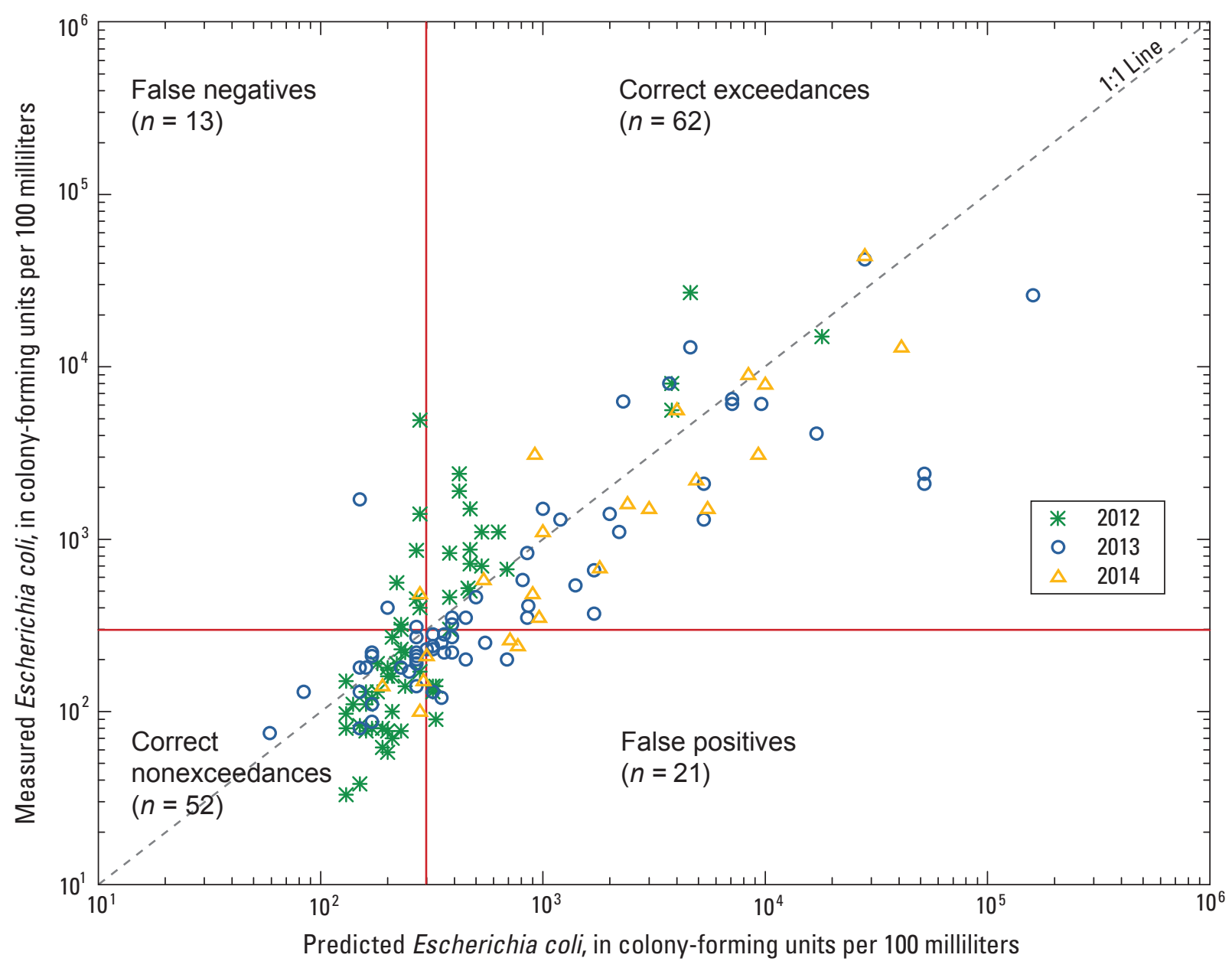

Figure 7. Predicted Escherichia coli (E. coli) concentrations from the predictive models for the Cuyahoga River at Jaite site (U.S. Geological Survey streamgage 04206425) compared with the measured E. coli concentrations at the Cuyahoga River near Lock 29 near Peninsula OH (U.S. Geological Survey streamgage 411433081330000) site in Cuyahoga Valley National Park, Ohio, during the recreational seasons (May through September) of 2012-14. The Ohio single-sample water-quality standard of 298 colony-forming units per 100 milliliters is shown on the plot as red lines. $n$, number of samples. 
Table 5. Correct and false positive and negative responses for recreational water-quality conditions using the nowcasts at Jaite and the persistence model for determining water quality at Lock 29, Cuyahoga Valley National Park, Ohio.

[The greatest percentages (correct, sensitivity, and specificity) by year are in bold. All samples (morning and afternoon) are reported. The persistence model is the previous day's Escherichia coli concentrations; sensitivity is the percentage of exceedances of the water-quality standard (WQS) that are correctly predicted by the model. Specificity is the percentage of nonexceedances of the WQS that correctly predicted by the model]

\begin{tabular}{|c|c|c|c|c|c|}
\hline \multirow{2}{*}{ Model } & \multirow{2}{*}{$\begin{array}{l}\text { Number of } \\
\text { samples }\end{array}$} & \multirow{2}{*}{$\begin{array}{l}\text { Exceedances of } \\
\text { WOS, in percent }\end{array}$} & \multicolumn{3}{|c|}{ Percentage } \\
\hline & & & Correct & Sensitivity & Specificity \\
\hline \multicolumn{6}{|c|}{2012} \\
\hline Nowcast & 62 & 43.5 & 79.0 & 66.7 & 88.6 \\
\hline Persistence model & 39 & 28.2 & 51.3 & 54.5 & 50.0 \\
\hline \multicolumn{6}{|c|}{2013} \\
\hline Nowcast & 63 & 49.2 & 73.0 & 90.3 & 56.2 \\
\hline Persistence model & 37 & 45.9 & 62.2 & 70.6 & 55.0 \\
\hline \multicolumn{6}{|c|}{2014} \\
\hline Nowcast & 23 & 73.9 & 82.6 & 94.1 & 50.0 \\
\hline Persistence model & 14 & 78.6 & 64.3 & 72.7 & 33.3 \\
\hline \multicolumn{6}{|c|}{ 2012-2014 } \\
\hline Nowcast & 148 & 50.7 & 77.0 & 82.7 & 71.2 \\
\hline Persistence model & 90 & 43.3 & 57.8 & 66.7 & 51.0 \\
\hline
\end{tabular}

\section{Reaching the Public}

To ensure information regarding water quality and the nowcasts were available to the public, the NPS and the USGS worked collaboratively to produce products designed to reach the public. These products included a news release, business cards with the Ohio Nowcast Web site address and quick response $(\mathrm{QR})$ code (a matrix barcode that can be scanned using a smart phone that resolves to the Ohio Nowcast Web site [http://www.ohionowcast.info/]), and seasonal signage at CVNP trailheads that provides a basic overview of water quality issues in the park and a link to the Ohio Nowcast Web site. Links to the Ohio Nowcast Web site are also posted on the CVNP Web and Facebook sites. The NPS also created and presented programs on water quality to park visitors. The news release was prepared prior to the recreational season of 2013 to publicize that nowcast predictions would be available daily on the Ohio Nowcast Web site using the automated process described in the "Running the Nowcast" section. The story was picked up by local news outlets in the northeastern Ohio region and, surprisingly, in Seattle, Washington, and San Francisco, California. The business cards, which were carried by NPS interns while sampling so that these could be handed out as needed to CVNP visitors, were also available at the CVNP visitor centers as a quick reference to the Ohio Nowcast Web site.

The number of visitors to the Ohio Nowcast CVNPspecific Web page by month is shown in figure 8 . Not surprisingly, there was a large increase in the number of visitors to the Web page in June 2013 after the news release. For the other months of the recreational season, each consecutive year shows an increase in the number of visits. Because the Ohio Nowcast Web site's main page also contains nowcast results for locations other than CVNP, the number of site visits to the main page was not tallied. The data shown in figure 8 demonstrate the number of visitors interested in more detailed information on the water quality of the river. 


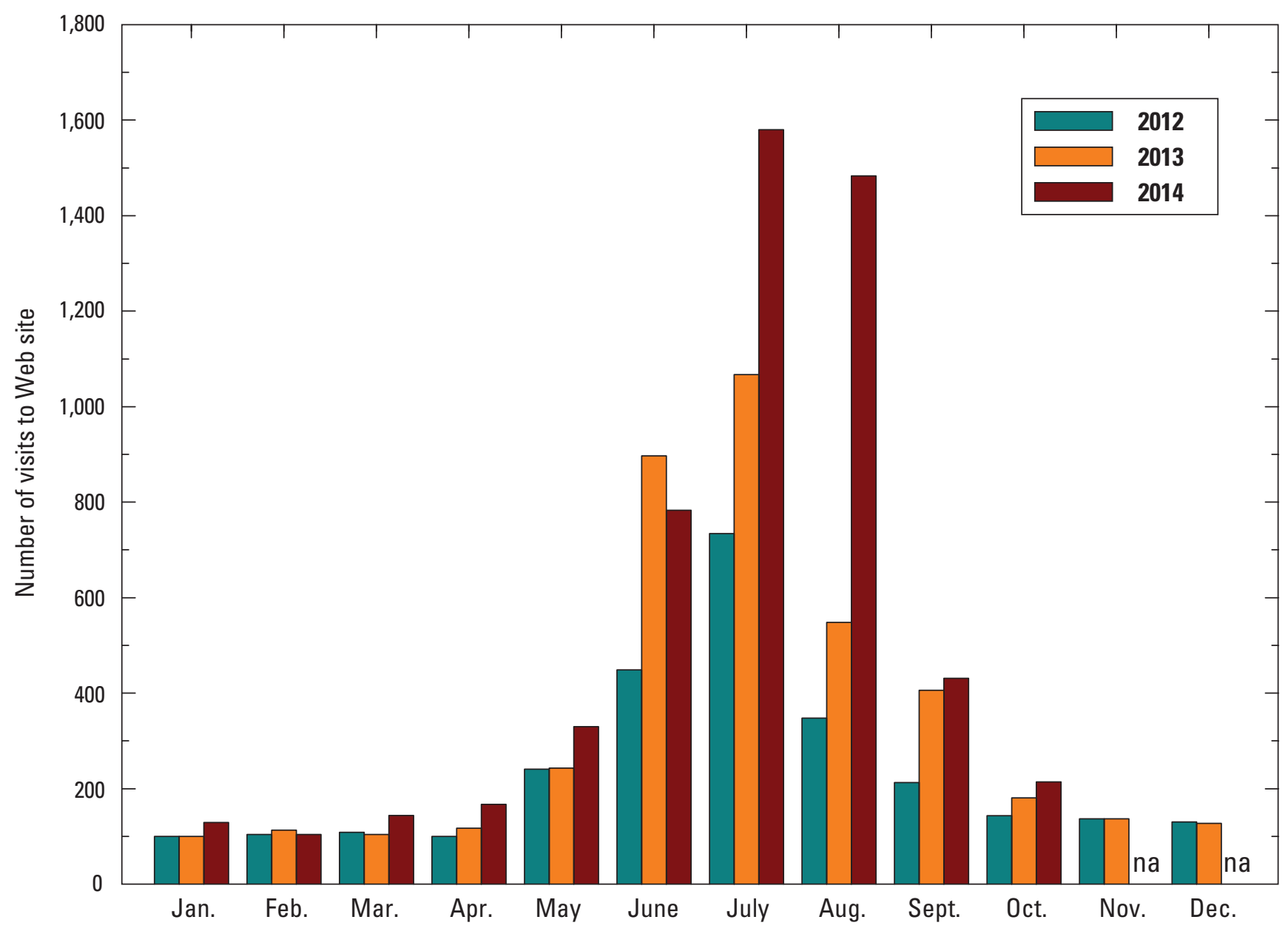

Figure 8. Number of visits to the Cuyahoga River Web page of the Ohio Nowcast Web site (http://www.ohionowcast.info/), by month, from 2012 through 2014. na, data not available. 


\section{Summary}

The U.S. Geological Survey (USGS) and the National Park Service have worked in collaboration since 2004 to develop a method to provide more timely results to the public regarding the recreational water quality of the Cuyahoga River within the Cuyahoga Valley National Park (CVNP). Previous research has shown that a turbidity-based predictive model could accurately predict recreational water quality above or below Ohio's single-sample standard for primary-contact recreation (water-quality standard, WQS) at one site on the river at Jaite, Ohio, for more than 80 percent of the samples collected. Prior to development of the predictive model, the estimates of recreational water quality were based on bacteria concentrations in previously collected samples, which has proven to be less accurate than the predictive model and also requires a sample to be collected and analyzed each day.

Nowcasts are systems that can provide estimates of the current bacterial water-quality conditions based on predictive models using easily-measured, explanatory variables; nowcasts can provide the public with the information to make informed decisions on the risk associated with recreational activities in natural water bodies. To streamline current implementation procedures for nowcast models at CVNP, three time-saving mechanisms were initiated during this study: (1) a USGS stream monitor with an in-stream turbidity sensor and near-real-time data transmission was installed at Jaite in May 2012; (2) a less labor-intensive method (Colilert) for determining Escherichia coli (E. coli) concentrations was instituted for use during nowcast testing; and (3) a computer program was developed to automatically run and post nowcast predictions on the Ohio Nowcast Web site (http://www.ohionowcast.info/) each day at 9 a.m.

During the recreational season of 2012, a relation between laboratory- and in-stream-measured turbidity was developed so nowcasts could be developed using the in-stream turbidity measurements. Starting during the recreational season of 2013, the Colilert method was used side-by-side with the membrane filtration method (used during previous studies) to determine $E$. coli concentrations in water samples. Although the membrane filtration appeared to report larger concentrations more frequently than the Colilert method, no significant differences in exceedances of the WQS were observed between the two methods during this study. The automated computer program ran during the recreational seasons of 2013 and 2014. The program retrieved required data and made and posted predictions to the Ohio Nowcast Web site by 9 a.m. each morning.
Afternoon samples were collected on several days of the recreational season of each year to determine if the daily predicted E. coli concentrations based on morning samples could accurately represent concentrations later in the day. The morning sample concentrations were a good representation of what the afternoon sample concentrations were, but due to the limited sampling schedule, more research would be required to better understand the diurnal changes in water quality.

Nowcasts were developed and tested each year of the study (2012 through 2014). Discrete water samples were collected at Jaite and at one upstream site, at Lock 29, to test nowcasts. Concentrations of $E$. coli were determined, and measurements of turbidity using a laboratory turbidimeter were made for all samples collected. Median concentrations of E. coli were statistically higher during the recreational seasons of 2013 and 2014 compared with those in the recreational season of 2012 for both sites. Relations between E. coli concentrations and water-quality and environmental variables were ascertained. Significant relations were found between E. coli and turbidity (laboratory- and in-stream measured), streamflow as reported at Jaite, and rainfall during the 24-hour period prior to 8 a.m. on the day prior to sampling. Nowcasts developed at Jaite varied somewhat each year, but always included turbidity and rainfall as explanatory variables. In comparison to the persistence model, the nowcasts consistently performed better based on two response statistics - percent correct responses and sensitivity. Specificity for the nowcast compared with the persistence model was lower during the 2013 and 2014 recreational seasons. The nowcasts also performed better than the persistence model when the Jaite nowcast predictions were compared with to the Lock 29 sample results. Understanding of the water quality in this stretch of the river is important because it is becoming a popular destination for kayaking. With the implementation of the scheduled and automated run of the computer program to post predicted recreational water quality conditions in the river 7 days per week, a news release was issued in June 2013 to provide the public information on how to understand and access the water-quality predictions and, therefore, allow the public to better assess potential recreational water-quality risks

Continued implementation of the CVNP nowcast is dependent on the availability of operating funds but is anticipated for summer 2015. Future studies at CVNP could include a more in-depth look at using the single nowcast to predict recreational water quality in the stretch of the river from Lock 29 to Jaite and (or) research to determine if a single nowcast could be used consistently for several years, eliminating the need for annual updates to the models. 


\section{References Cited}

Brady, A.M.G., and Plona, M.B., 2009, Relations between environmental and water-quality variables and Escherichia coli in the Cuyahoga River with emphasis on turbidity as a predictor of recreational water quality, Cuyahoga Valley National Park, Ohio, 2008: U.S. Geological Survey OpenFile Report 2009-1192, 6 p. [Also available at http://pubs. usgs.gov/of/2009/1192/.]

Brady, A.M.G., and Plona, M.B., 2012, Development and implementation of a regression model for predicting recreational water quality in the Cuyahoga River, Cuyahoga Valley National Park, Ohio 2009-11: U.S. Geological Survey Scientific Investigations Report 2012-5074, 14 p. [Also available at http://pubs.usgs.gov/sir/2012/5074/.]

Brady, A.M.G., Bushon, R.N., and Plona, M.B., 2009, Predicting recreational water quality using turbidity in the Cuyahoga River, Cuyahoga Valley National Park, Ohio, 2004-7: U.S. Geological Survey Scientific Investigations Report 2009-5192, 16 p. [Also available at http://pubs.usgs. gov/sir/2009/5192/.]

Dunn, O.J., 1964, Multiple comparisons using rank sums: Technometrics, v. 6, no. 3, p. 241-252.

Francy, D.S., Brady, A.M.G., Carvin, R.B., Corsi, S.R., Fuller, L.M., Harrison, J.H., Hayhurst, B.A., Lant, Jeremiah, Nevers, M.B., Terrio, P.J., and Zimmerman, T.M., 2013, Developing and implementing predictive models for estimating recreational water quality at Great Lakes beaches: U.S. Geological Survey Scientific Investigations Report 2013-5166, 68 p. plus appendixes. [Also available at http:// pubs.usgs.gov/sir/2013/5166/.]

Francy, D.S., Bushon, R.N., Brady, A.M.G., Kephart, C.M., Stelzer, E.A., and Ecker, C.D., 2014, Quality assurance/ quality control manual-Ohio Water Microbiology Laboratory: U.S. Geological Survey Web page, accessed October 2014 at http://oh.water.usgs.gov/micro_qaqc.htm.

Francy D.S. and Darner, R.A., 2000, Comparisons of methods for determining Escherichia coli concentrations in recreational waters: Water Research, v. 34, no. 10, p. 2770-2778.

Francy, D.S., and Darner, R.A., 2006, Procedures for developing models to predict exceedances of recreational waterquality standards at coastal beaches: U.S. Geological Survey Techniques and Methods, book 6, chap. B5, 34 p., accessed October 2014 at http://pubs.usgs.gov/tm/2006/ tm6b5/.
Francy, D.S., Darner, R.A., and Bertke, E.E., 2006, Models for predicting recreational water quality at Lake Erie beaches: U.S. Geological Survey Scientific Investigations Report 2006-5192, 13 p. [Also available at http://pubs.usgs.gov/ sir/2006/5192/.]

Helsel, D.R. and Hirsch, R.M., 2002, Statistical methods in water resources: U.S. Geological Survey Techniques of Water Resources Investigations, book 4, chap. A3, 522 p. [Also available at http://pubs.usgs.gov/twri/twri4a3/.]

Kinzelman, J.L., Singh, Ajaib, Ng, Clem, Pond, K.R., Bagley, R.C., and Gradus, Stephen, 2005, Use of IDEXX Colilert-18 ${ }^{\circledR}$ and Quanti-Tray/2000 as a rapid and simple enumeration method for the implementation of recreational water monitoring and notification programs: Lake and Reservoir Management, v. 22, no. 1, p. 73-77.

McNemar, Quinn, 1947, Note on the sampling error of the difference between correlated proportions or percentages: Psychometrika, v. 12, no. 2, p. 153-157.

Myers, D.N., Stoeckel, D.M., Bushon, R.N., Francy, D.S., and Brady, A.M.G., 2014, Fecal indicator bacteria (ver. 2.1), sec. 7.1 of Biological indicators: U.S. Geological Survey Techniques of Water-Resources Investigations, book 9, chap. A7, 73 p., accessed January 2015 at http://pubs.water. usgs.gov/twri9A/.

National Park Service, 2015, Cuyahoga Valley National Park: National Park Service visitor use statistics Web site, accessed April 2015 at https://irma.nps.gov/Stats/Reports/ Park/CUVA.

National Oceanic and Atmospheric Administration, 2014a, Meteorological assimilation data ingest system: National Oceanic and Atmospheric Administration Web site, accessed January 2015 at http://madis.noaa.gov/.

National Oceanic and Atmospheric Administration, 2014b, Quality controlled local climatological data: National Oceanic and Atmospheric Administration National Climatic Data Center Web site, accessed October 2014 at http://cdo.ncdc.noaa.gov/qclcd/QCLCD?prior=N.

National Oceanic and Atmospheric Administration, 2014c, Weather observations for the past three days - Akron Fulton International Airport: National Oceanic and Atmospheric Administration National Weather Service Web page, accessed October 2014 at http:/www.nws.noaa.gov/obhistory/KAKR.html.

Ohio Environmental Protection Agency, 2003, Total maximum daily loads for the lower Cuyahoga River, final report: Columbus, Ohio, Ohio Environmental Protection Agency, $102 \mathrm{p}$. 
Ohio Environmental Protection Agency, 2014, OAC chapter 3745-1 water quality standards: Ohio Environmental Protection Agency Ohio administrative code, accessed October 2014 at http://epa.ohio.gov/dsw/rules/3745_1.aspx.

Rantz, S.E., and others, 1982a, Computation of discharge, v. 2 of Measurement and computation of streamflow: U.S. Geological Survey Water-Supply Paper 2175, p. 285-631. [Also available at http://pubs.usgs.gov/wsp/wsp2175/.]

Rantz, S.E., and others, 1982b, Measurement of stage, v. 1 of Measurement and computation of streamflow: U.S. Geological Survey Water-Supply Paper 2175, p. 1-284. [Also available at http://pubs.usgs.gov/wsp/wsp2175/.]

Rice, E.W., Baird, R.B., Eaton, A.D., and Clesceri, L.S., eds.,, 2006, Standard methods for the examination of water and wastewater (22d ed.): Washington, D.C., American Public Health Association, American Water Works Association, and Water Environment Federation, 1,496 p., accessed October 2014 at http://www.standardmethods.org/.

U.S. Environmental Protection Agency, 2009, Method $1603-$ Escherichia coli (E. coli) in water by membrane filtration using modified membrane-thermotolerant Escherichia coli agar (modified mTEC): Washington, D.C., U.S. Environmental Protection Agency EPA-821-R-09-007, 36 p., accessed October 2014 at http://water.epa.gov/scitech/methods/cwa/bioindicators/upload/method_1603.pdf.
U.S. Environmental Protection Agency, 2014, Virtual beach (VB): U.S. Environmental Protection Agency exposure assessment models Web page, accessed October 2014 at http://www2.epa.gov/exposure-assessment-models/virtualbeach-vb.

U.S. Geological Survey, 2006, Collection of water samples (version 2.0): U.S. Geological Survey Techniques of WaterResources Investigations, book 9, chap. A4, 166 p. plus appendixes, accessed October 2014 at http://water.usgs.gov/ owq/FieldManual/chapter4/pdf/Chap4_v2.pdf.

U. S. Geological Survey, 2015, Water quality samples for Ohio_-USGS 04206425 Cuyahoga River at Jaite OH: U.S. Geological Survey National Water Information System Web interface, accessed April 2015 at http://nwis.waterdata. usgs.gov/oh/nwis/qwdata/?site_no=04206425\&agency_ $\mathrm{cd}=\mathrm{USGS}$.

Wagner, R.J., Boulger, R.W., Jr., Oblinger, C.J., and Smith, B.A., 2006, Guidelines and standard procedures for continuous water-quality monitors - Station operation, record computation, and data reporting: U.S. Geological Survey Techniques and Methods, book 1, chap. D3, 51 p. plus 8 appendixes. [Also available at http://pubs.usgs.gov/ $\mathrm{tm} / 2006 / \mathrm{tm} 1 \mathrm{D} 3 /$.

Wilcoxon, Frank, 1945, Individual comparisons by ranking methods: Biometrics Bulletin, v. 1, no. 6, p. 80-83. 


\section{Appendix 1.}

Nowcast Predictions for the Cuyahoga River at Jaite, Cuyahoga Valley National Park, 2012-14 
Table 1-1. Nowcast predictions for the Cuyahoga River at Jaite sampling site in the Cuyahoga Valley National Park, 2012-14.

[Indicated in the notes are dates when the predicted water quality was not reported to the Ohio Nowcast Web site (http://www.ohionowcast.info/) due to issues with the Web site or scheduled run of the computer program used to update the Web site. Morning samples were generally collected prior to 9 a.m.; afternoon samples were collected after 12 p.m. NTRU, nephelometric turbidity ratio unit; FNU, formazin nephelometric unit; E. coli, Escherichia coli; --, no data available; CFU/100 $\mathrm{mL}$, colony-forming unit per 100 milliliters; $\mathrm{MNP} / 100 \mathrm{~mL}$, most-probable number per 100 milliliters]

\begin{tabular}{|c|c|c|c|c|c|c|c|}
\hline Date & $\begin{array}{c}\text { Observed } \\
\text { turbidity, } \\
\text { in NTRU (2012) } \\
\text { or FNU } \\
(2013,2014)\end{array}$ & $\begin{array}{c}\text { Morning } \\
\text { actual } E \text {. coli, } \\
\text { in CFU/100 mL } \\
\text { unless } \\
\text { otherwise noted }\end{array}$ & $\begin{array}{c}\text { Afternoon } \\
\text { actual } E \text {. coli, } \\
\text { in CFU/100 mL } \\
\text { unless } \\
\text { otherwise noted }\end{array}$ & $\begin{array}{c}\text { Predicted } \\
\text { E. coli, in } \\
\text { CFU/100 } \\
\mathrm{mL}\end{array}$ & $\begin{array}{c}\text { Predicted } \\
\text { water } \\
\text { quality }^{1}\end{array}$ & $\begin{array}{c}\text { Nowcast } \\
\text { used }^{2}\end{array}$ & Notes \\
\hline $05 / 23 / 12$ & 6.9 & 77 & -- & 140 & Good & 2012 & \\
\hline $05 / 25 / 12$ & 6.2 & 110 & 60 & 130 & Good & 2012 & \\
\hline $05 / 30 / 12$ & 59 & 27,000 & -- & 4,600 & Poor & 2012 & \\
\hline $06 / 01 / 12$ & 13 & 2,100 & 1,900 & 420 & Poor & 2012 & \\
\hline $06 / 04 / 12$ & 15 & 580 & 450 & 270 & Good & 2012 & \\
\hline $06 / 06 / 12$ & 13 & 340 & -- & 460 & Poor & 2012 & \\
\hline $06 / 11 / 12$ & 8 & 180 & 130 & 160 & Good & 2012 & \\
\hline $06 / 13 / 12$ & 8.1 & 140 & 63 & 210 & Good & 2012 & \\
\hline $06 / 15 / 12$ & 7.6 & 170 & 73 & 160 & Good & 2012 & \\
\hline 06/17/12 & 8.2 & 120 & 67 & 330 & Poor & 2012 & \\
\hline $06 / 20 / 12$ & 16 & 670 & 550 & 470 & Poor & 2012 & \\
\hline $06 / 22 / 12$ & 12 & 380 & 200 & 230 & Good & 2012 & \\
\hline $06 / 25 / 12$ & 12 & 200 & 93 & 220 & Good & 2012 & \\
\hline $06 / 27 / 12$ & 10 & 85 & 73 & 200 & Good & 2012 & \\
\hline 06/29/12 & 8.3 & 70 & 110 & 170 & Good & 2012 & \\
\hline $07 / 02 / 12$ & 7.2 & 80 & 28 & 190 & Good & 2012 & \\
\hline 07/04/12 & 19 & 1,500 & -- & 630 & Poor & 2012 & \\
\hline $07 / 06 / 12$ & 9 & 110 & 210 & 320 & Poor & 2012 & \\
\hline 07/09/12 & 6 & 77 & 40 & 130 & Good & 2012 & \\
\hline 07/11/12 & 7 & 82 & 19 & 150 & Good & 2012 & \\
\hline 07/13/12 & 12 & 480 & 500 & 530 & Poor & 2012 & \\
\hline $07 / 16 / 12$ & 11 & 260 & 180 & 470 & Poor & 2012 & \\
\hline $07 / 20 / 12$ & 53 & 12,000 & 4,600 & 3,800 & Poor & 2012 & \\
\hline $07 / 23 / 12$ & 12 & 190 & -- & 230 & Good & 2012 & \\
\hline $07 / 25 / 12$ & 12 & 130 & 53 & 230 & Good & 2012 & \\
\hline $07 / 27 / 12$ & 450 & 78,000 & -- & 18,000 & Poor & 2012 & \\
\hline $07 / 30 / 12$ & 23 & 780 & -- & 380 & Poor & 2012 & \\
\hline $08 / 01 / 12$ & 13 & 620 & 210 & 280 & Good & 2012 & \\
\hline 08/03/12 & 10 & 170 & 200 & 200 & Good & 2012 & \\
\hline $08 / 06 / 12$ & 16 & 4,800 & 1,400 & 280 & Good & 2012 & \\
\hline 08/08/12 & 9.2 & 150 & 180 & 180 & Good & 2012 & \\
\hline 08/10/12 & 10 & 420 & -- & 690 & Poor & 2012 & \\
\hline $08 / 13 / 12$ & 18 & 490 & 300 & 380 & Poor & 2012 & \\
\hline $08 / 15 / 12$ & 11 & 310 & 120 & 210 & Good & 2012 & \\
\hline $08 / 17 / 12$ & 13 & 160 & 130 & 240 & Good & 2012 & \\
\hline $08 / 20 / 12$ & 11 & 100 & 180 & 540 & Poor & 2012 & \\
\hline $08 / 24 / 12$ & 9.7 & 140 & -- & 190 & Good & 2012 & \\
\hline 05/18/13 & 4.8 & -- & -- & 82 & Good & 2013 & \\
\hline 05/19/13 & 4.3 & -- & -- & 84 & Good & 2013 & \\
\hline
\end{tabular}


Table 1-1. Nowcast predictions for the Cuyahoga River at Jaite sampling site in the Cuyahoga Valley National Park, 2012-14.—Continued

[Indicated in the notes are dates when the predicted water quality was not reported to the Ohio Nowcast Web site (http://www.ohionowcast.info/) due to issues with the Web site or scheduled run of the computer program used to update the Web site. Morning samples were generally collected prior to 9 a.m.; afternoon samples were collected after 12 p.m. NTRU, nephelometric turbidity ratio unit; FNU, formazin nephelometric unit; E. coli, Escherichia coli; --, no data available; CFU/100 $\mathrm{mL}$, colony-forming unit per 100 milliliters; MNP/100 mL, most-probable number per 100 milliliters]

\begin{tabular}{|c|c|c|c|c|c|c|c|}
\hline Date & $\begin{array}{c}\text { Observed } \\
\text { turbidity, } \\
\text { in NTRU (2012) } \\
\text { or FNU } \\
(2013,2014)\end{array}$ & $\begin{array}{l}\text { Morning } \\
\text { actual } E \text {. coli, } \\
\text { in CFU/100 mL } \\
\text { unless } \\
\text { otherwise noted }\end{array}$ & $\begin{array}{c}\text { Afternoon } \\
\text { actual } E \text {. coli, } \\
\text { in CFU/100 mL } \\
\text { unless } \\
\text { otherwise noted }\end{array}$ & $\begin{array}{l}\text { Predicted } \\
\text { E. coli, in } \\
\text { CFU/100 } \\
\quad \mathrm{mL}\end{array}$ & $\begin{array}{l}\text { Predicted } \\
\text { water } \\
\text { quality }^{1}\end{array}$ & $\begin{array}{c}\text { Nowcast } \\
\text { used }^{2}\end{array}$ & Notes \\
\hline $05 / 20 / 13$ & 4.6 & -- & -- & 78 & Good & 2013 & \\
\hline $05 / 21 / 13$ & 4 & -- & -- & 67 & Good & 2013 & \\
\hline $05 / 22 / 13$ & 3.6 & 83 & -- & 59 & Good & 2013 & \\
\hline $05 / 23 / 13$ & 4.9 & 250 & -- & 84 & Good & 2013 & \\
\hline $05 / 24 / 13$ & 7.1 & 330 & -- & 150 & Good & 2013 & \\
\hline $05 / 25 / 13$ & 6.1 & -- & -- & 190 & Good & 2013 & \\
\hline $05 / 26 / 13$ & 5.5 & -- & -- & 96 & Good & 2013 & \\
\hline $05 / 27 / 13$ & 6.2 & -- & -- & 110 & Good & 2013 & \\
\hline $05 / 28 / 13$ & 17 & -- & -- & 340 & Poor & 2013 & \\
\hline $05 / 29 / 13$ & 14 & 93 & -- & 690 & Poor & 2013 & \\
\hline $05 / 30 / 13$ & 7.2 & 330 & -- & 200 & Good & 2013 & \\
\hline $05 / 31 / 13$ & 8 & 180 & -- & 150 & Good & 2013 & \\
\hline 06/01/13 & 94 & -- & -- & 2,400 & Poor & 2013 & \\
\hline $06 / 02 / 13$ & 300 & -- & -- & 20,000 & Poor & 2013 & \\
\hline $06 / 03 / 13$ & 42 & -- & -- & 3,400 & Poor & 2013 & \\
\hline $06 / 04 / 13$ & 27 & -- & -- & 710 & Poor & 2013 & \\
\hline $06 / 05 / 13$ & 26 & 380 & -- & 550 & Poor & 2013 & \\
\hline $06 / 06 / 13$ & 24 & 400 & -- & 500 & Poor & 2013 & \\
\hline 06/07/13 & 93 & 7,700 & -- & 9,600 & Poor & 2013 & \\
\hline $06 / 08 / 13$ & 49 & -- & -- & 4,600 & Poor & 2013 & \\
\hline 06/09/13 & 30 & -- & -- & 650 & Poor & 2013 & \\
\hline $06 / 10 / 13$ & 25 & -- & -- & 530 & Poor & 2013 & \\
\hline $06 / 11 / 13$ & 670 & -- & -- & 32,000 & Poor & 2013 & \\
\hline $06 / 12 / 13$ & 32 & 420 & -- & 1,400 & Poor & 2013 & \\
\hline $06 / 13 / 13$ & 140 & 4,500 & -- & 3,700 & Poor & 2013 & \\
\hline $06 / 14 / 13$ & 38 & 2,000 & -- & 2,000 & Poor & 2013 & \\
\hline $06 / 15 / 13$ & 25 & -- & -- & 530 & Poor & 2013 & \\
\hline $06 / 16 / 13$ & 25 & -- & -- & 430 & Poor & 2013 & \\
\hline $06 / 17 / 13$ & 50 & -- & -- & 2,100 & Poor & 2013 & \\
\hline $06 / 18 / 13$ & 26 & -- & -- & 1,100 & Poor & 2013 & \\
\hline 06/19/13 & 19 & 250 & -- & 860 & Poor & 2013 & \\
\hline $06 / 20 / 13$ & 16 & -- & -- & 320 & Poor & 2013 & \\
\hline $06 / 21 / 13$ & 12 & 250 & -- & 230 & Good & 2013 & \\
\hline $06 / 22 / 13$ & 9.5 & -- & -- & 180 & Good & 2013 & \\
\hline $06 / 23 / 13$ & 8 & -- & -- & 150 & Good & 2013 & \\
\hline $06 / 24 / 13$ & 7.1 & -- & -- & 130 & Good & 2013 & \\
\hline $06 / 25 / 13$ & 6.4 & -- & -- & 110 & Good & 2013 & \\
\hline $06 / 26 / 13$ & 850 & 41,000 & -- & 28,000 & Poor & 2013 & \\
\hline $06 / 27 / 13$ & 75 & 3,000 & -- & 17,000 & Poor & 2013 & \\
\hline
\end{tabular}


Table 1-1. Nowcast predictions for the Cuyahoga River at Jaite sampling site in the Cuyahoga Valley National Park, 2012-14.—Continued

[Indicated in the notes are dates when the predicted water quality was not reported to the Ohio Nowcast Web site (http://www.ohionowcast.info/) due to issues with the Web site or scheduled run of the computer program used to update the Web site. Morning samples were generally collected prior to 9 a.m.; afternoon samples were collected after 12 p.m. NTRU, nephelometric turbidity ratio unit; FNU, formazin nephelometric unit; E. coli, Escherichia coli; --, no data available; CFU/100 $\mathrm{mL}$, colony-forming unit per 100 milliliters; MNP/100 mL, most-probable number per 100 milliliters]

\begin{tabular}{|c|c|c|c|c|c|c|c|}
\hline Date & $\begin{array}{c}\text { Observed } \\
\text { turbidity, } \\
\text { in NTRU (2012) } \\
\text { or FNU } \\
(2013,2014)\end{array}$ & $\begin{array}{c}\text { Morning } \\
\text { actual } E \text {. coli, } \\
\text { in CFU/100 mL } \\
\text { unless } \\
\text { otherwise noted }\end{array}$ & $\begin{array}{c}\text { Afternoon } \\
\text { actual } E \text {. coli, } \\
\text { in CFU/100 mL } \\
\text { unless } \\
\text { otherwise noted }\end{array}$ & $\begin{array}{c}\text { Predicted } \\
\text { E. coli, in } \\
\text { CFU/100 } \\
\text { mL }\end{array}$ & $\begin{array}{c}\text { Predicted } \\
\text { water } \\
\text { quality }^{1}\end{array}$ & $\begin{array}{c}\text { Nowcast } \\
\text { used }^{2}\end{array}$ & Notes \\
\hline $06 / 28 / 13$ & 50 & 1,000 & -- & 2,200 & Poor & 2013 & \\
\hline $06 / 29 / 13$ & 43 & -- & -- & 1,200 & Poor & 2013 & \\
\hline $06 / 30 / 13$ & 86 & -- & -- & 6,700 & Poor & 2013 & \\
\hline 07/01/13 & 43 & 1,300 & -- & 1,200 & Poor & 2013 & \\
\hline $07 / 02 / 13$ & 92 & 7,900 & -- & 2,300 & Poor & 2013 & \\
\hline $07 / 03 / 13$ & 26 & 650 & -- & 810 & Poor & 2013 & \\
\hline $07 / 08 / 13$ & 27 & -- & -- & 850 & Poor & 2013 & \\
\hline 07/09/13 & 490 & -- & -- & 15,000 & Poor & 2013 & \\
\hline $07 / 10 / 13$ & 1790 & 12,000 & -- & 160,000 & Poor & 2013 & \\
\hline $07 / 11 / 13$ & 370 & -- & -- & 60,000 & Poor & 2013 & \\
\hline $07 / 12 / 13$ & 180 & -- & -- & 52,000 & Poor & 2013 & \\
\hline $07 / 13 / 13$ & 120 & -- & -- & 3,100 & Poor & 2013 & \\
\hline $07 / 14 / 13$ & 79 & -- & -- & 1,900 & Poor & 2013 & \\
\hline $07 / 15 / 13$ & 66 & -- & -- & 1,600 & Poor & 2013 & \\
\hline $07 / 16 / 13$ & 57 & -- & -- & 1,300 & Poor & 2013 & \\
\hline $07 / 18 / 13$ & 42 & -- & -- & 1,800 & Poor & 2013 & \\
\hline $07 / 19 / 13$ & 36 & -- & -- & 800 & Poor & 2013 & \\
\hline $07 / 20 / 13$ & 66 & -- & -- & 1,600 & Poor & 2013 & \\
\hline $07 / 21 / 13$ & 54 & -- & -- & 2,300 & Poor & 2013 & \\
\hline $07 / 22 / 13$ & 39 & -- & -- & 2,000 & Poor & 2013 & \\
\hline $07 / 23 / 13$ & 40 & -- & -- & 1,600 & Poor & 2013 & \\
\hline $07 / 24 / 13$ & 140 & -- & -- & 5,600 & Poor & 2013 & \\
\hline $07 / 25 / 13$ & 36 & 1,300 & 700 & 1,000 & Poor & 2013 & \\
\hline $07 / 26 / 13$ & 29 & -- & 700 & 620 & Poor & 2013 & \\
\hline $07 / 27 / 13$ & 27 & -- & -- & 580 & Poor & 2013 & \\
\hline $07 / 28 / 13$ & 32 & -- & -- & 700 & Poor & 2013 & \\
\hline $07 / 29 / 13$ & 25 & -- & -- & 1,000 & Poor & 2013 & \\
\hline $07 / 30 / 13$ & 19 & -- & -- & 390 & Poor & 2013 & \\
\hline $07 / 31 / 13$ & 14 & 180 & 170 & 270 & Good & 2013 & \\
\hline $08 / 01 / 13$ & 13 & 180 & 190 & 250 & Good & 2013 & \\
\hline $08 / 02 / 13$ & 8.9 & 120 & 150 & 160 & Good & 2013 & \\
\hline $08 / 03 / 13$ & 8.5 & -- & -- & 160 & Good & 2013 & \\
\hline $08 / 04 / 13$ & 110 & -- & -- & 5,800 & Poor & 2013 & \\
\hline $08 / 05 / 13$ & 11 & -- & -- & 240 & Good & 2013 & \\
\hline $08 / 06 / 13$ & 7.1 & -- & -- & 130 & Good & 2013 & \\
\hline 08/07/13 & 6.2 & -- & -- & 110 & Good & 2013 & \\
\hline $08 / 08 / 13$ & 170 & 16,000 & 4,000 & 4,600 & Poor & 2013 & \\
\hline 08/09/13 & 120 & -- & -- & 7,100 & Poor & 2013 & \\
\hline 08/10/13 & 56 & -- & -- & 2,600 & Poor & 2013 & \\
\hline
\end{tabular}


Table 1-1. Nowcast predictions for the Cuyahoga River at Jaite sampling site in the Cuyahoga Valley National Park, 2012-14.—Continued

[Indicated in the notes are dates when the predicted water quality was not reported to the Ohio Nowcast Web site (http://www.ohionowcast.info/) due to issues with the Web site or scheduled run of the computer program used to update the Web site. Morning samples were generally collected prior to 9 a.m.; afternoon samples were collected after 12 p.m. NTRU, nephelometric turbidity ratio unit; FNU, formazin nephelometric unit; E. coli, Escherichia coli; --, no data available; CFU/100 $\mathrm{mL}$, colony-forming unit per 100 milliliters; MNP/100 mL, most-probable number per 100 milliliters]

\begin{tabular}{|c|c|c|c|c|c|c|c|}
\hline Date & $\begin{array}{c}\text { Observed } \\
\text { turbidity, } \\
\text { in NTRU (2012) } \\
\text { or FNU } \\
(2013,2014)\end{array}$ & $\begin{array}{l}\text { Morning } \\
\text { actual } E \text {. coli, } \\
\text { in CFU/100 mL } \\
\text { unless } \\
\text { otherwise noted }\end{array}$ & $\begin{array}{c}\text { Afternoon } \\
\text { actual E. coli, } \\
\text { in CFU/100 mL } \\
\text { unless } \\
\text { otherwise noted }\end{array}$ & $\begin{array}{l}\text { Predicted } \\
\text { E. coli, in } \\
\text { CFU/100 } \\
\text { mL }\end{array}$ & $\begin{array}{l}\text { Predicted } \\
\text { water } \\
\text { quality }^{1}\end{array}$ & $\begin{array}{c}\text { Nowcast } \\
\text { used }^{2}\end{array}$ & Notes \\
\hline 08/11/13 & 28 & -- & -- & 600 & Poor & 2013 & \\
\hline $08 / 12 / 13$ & 19 & -- & -- & 520 & Poor & 2013 & \\
\hline 08/13/13 & 17 & -- & -- & 340 & Poor & 2013 & \\
\hline $08 / 14 / 13$ & 18 & 280 & 210 & 450 & Poor & 2013 & \\
\hline $08 / 15 / 13$ & 16 & 260 & 160 & 320 & Poor & 2013 & \\
\hline $08 / 16 / 13$ & 14 & 260 & 150 & 270 & Good & 2013 & \\
\hline $08 / 17 / 13$ & 13 & -- & -- & 250 & Good & 2013 & Not reported to Web site \\
\hline $08 / 18 / 13$ & 11 & -- & -- & 210 & Good & 2013 & Not reported to Web site \\
\hline 08/19/13 & 10 & -- & -- & 190 & Good & 2013 & Not reported to Web site \\
\hline $08 / 20 / 13$ & 9.8 & -- & -- & 180 & Good & 2013 & Not reported to Web site \\
\hline $08 / 21 / 13$ & 9.2 & 210 & 87 & 170 & Good & 2013 & \\
\hline $08 / 22 / 13$ & 8.2 & 170 & 110 & 150 & Good & 2013 & \\
\hline $08 / 23 / 13$ & 9.3 & 170 & 150 & 170 & Good & 2013 & \\
\hline $08 / 24 / 13$ & 7.9 & -- & -- & 210 & Good & 2013 & Not reported to Web site \\
\hline $08 / 25 / 13$ & 7.7 & -- & -- & 140 & Good & 2013 & Not reported to Web site \\
\hline $08 / 26 / 13$ & 8.2 & -- & -- & 150 & Good & 2013 & \\
\hline $08 / 27 / 13$ & 7.9 & -- & -- & 140 & Good & 2013 & \\
\hline $08 / 28 / 13$ & 68 & -- & -- & 2,400 & Poor & 2013 & \\
\hline $08 / 29 / 13$ & 35 & -- & -- & 3,200 & Poor & 2013 & \\
\hline 09/04/13 & 22 & 650 & 440 & 1,700 & Poor & 2013 & \\
\hline 09/05/13 & 19 & 350 & 280 & 390 & Poor & 2013 & \\
\hline $09 / 06 / 13$ & 18 & 320 & 250 & 360 & Poor & 2013 & \\
\hline 09/07/13 & 18 & 330 & -- & 360 & Poor & 2013 & \\
\hline 09/08/13 & 16 & -- & -- & 320 & Poor & 2013 & \\
\hline 09/09/13 & 15 & -- & -- & 300 & Poor & 2013 & \\
\hline 09/10/13 & 14 & -- & -- & 270 & Good & 2013 & \\
\hline 09/11/13 & 14 & 300 & 220 & 350 & Poor & 2013 & \\
\hline $09 / 12 / 13$ & 38 & 710 & 1,000 & 850 & Poor & 2013 & \\
\hline $09 / 13 / 13$ & 170 & 6,000 & 2,400 & 5,300 & Poor & 2013 & \\
\hline 09/14/13 & 36 & 2,200 & -- & 2,600 & Poor & 2013 & \\
\hline 09/15/13 & 19 & -- & -- & 480 & Poor & 2013 & \\
\hline 09/16/13 & 16 & -- & -- & 320 & Poor & 2013 & \\
\hline 09/17/13 & 14 & -- & -- & 400 & Poor & 2013 & \\
\hline $09 / 18 / 13$ & 14 & 290 & 220 & 270 & Good & 2013 & \\
\hline 09/19/13 & 16 & 310 & 240 & 320 & Poor & 2013 & \\
\hline $09 / 20 / 13$ & 14 & 270 & 200 & 270 & Good & 2013 & \\
\hline $09 / 21 / 13$ & 220 & -- & -- & 6,100 & Poor & 2013 & \\
\hline $09 / 22 / 13$ & 83 & -- & -- & 9,600 & Poor & 2013 & \\
\hline $09 / 23 / 13$ & 42 & -- & -- & 4,000 & Poor & 2013 & \\
\hline
\end{tabular}


Table 1-1. Nowcast predictions for the Cuyahoga River at Jaite sampling site in the Cuyahoga Valley National Park, 2012-14.-Continued

[Indicated in the notes are dates when the predicted water quality was not reported to the Ohio Nowcast Web site (http://www.ohionowcast.info/) due to issues with the Web site or scheduled run of the computer program used to update the Web site. Morning samples were generally collected prior to 9 a.m.; afternoon samples were collected after 12 p.m. NTRU, nephelometric turbidity ratio unit; FNU, formazin nephelometric unit; E. coli, Escherichia coli; --, no data available; CFU/100 $\mathrm{mL}$, colony-forming unit per 100 milliliters; $\mathrm{MNP} / 100 \mathrm{~mL}$, most-probable number per 100 milliliters]

\begin{tabular}{|c|c|c|c|c|c|c|c|}
\hline Date & $\begin{array}{c}\text { Observed } \\
\text { turbidity, } \\
\text { in NTRU (2012) } \\
\text { or FNU } \\
(2013,2014)\end{array}$ & $\begin{array}{c}\text { Morning } \\
\text { actual } E \text {. coli, } \\
\text { in CFU/100 mL } \\
\text { unless } \\
\text { otherwise noted }\end{array}$ & $\begin{array}{c}\text { Afternoon } \\
\text { actual } E \text {. coli, } \\
\text { in CFU/100 mL } \\
\text { unless } \\
\text { otherwise noted }\end{array}$ & $\begin{array}{l}\text { Predicted } \\
\text { E. coli, in } \\
\text { CFU/100 } \\
\mathrm{mL}\end{array}$ & $\begin{array}{c}\text { Predicted } \\
\text { water } \\
\text { quality }^{1}\end{array}$ & $\begin{array}{c}\text { Nowcast } \\
\text { used }^{2}\end{array}$ & Notes \\
\hline $09 / 24 / 13$ & 26 & -- & -- & 550 & Poor & 2013 & \\
\hline $09 / 25 / 13$ & 19 & 470 & 290 & 390 & Poor & 2013 & \\
\hline $09 / 26 / 13$ & 15 & 240 & -- & 300 & Poor & 2013 & \\
\hline $09 / 27 / 13$ & 14 & -- & -- & 270 & Good & 2013 & \\
\hline $09 / 28 / 13$ & 14 & -- & -- & 270 & Good & 2013 & \\
\hline 09/29/13 & 12 & -- & -- & 230 & Good & 2013 & \\
\hline $09 / 30 / 13$ & 11 & -- & -- & 210 & Good & 2013 & \\
\hline $10 / 01 / 13$ & 9.7 & -- & -- & 210 & Good & 2013 & \\
\hline $10 / 02 / 13$ & 8.5 & -- & -- & 160 & Good & 2013 & \\
\hline $10 / 03 / 13$ & 8.4 & -- & -- & 150 & Good & 2013 & \\
\hline $10 / 04 / 13$ & 43 & -- & -- & 1,200 & Poor & 2013 & \\
\hline $10 / 05 / 13$ & 13 & -- & -- & 740 & Poor & 2013 & \\
\hline $10 / 08 / 13$ & 40 & -- & -- & 900 & Poor & 2013 & \\
\hline $10 / 09 / 13$ & 22 & -- & -- & 460 & Poor & 2013 & Not reported to Web site \\
\hline $10 / 10 / 13$ & 17 & -- & -- & 340 & Poor & 2013 & Not reported to Web site \\
\hline $10 / 11 / 13$ & 15 & -- & -- & 300 & Poor & 2013 & Not reported to Web site \\
\hline $10 / 13 / 13$ & 11 & -- & -- & 210 & Good & 2013 & Not reported to Web site \\
\hline $10 / 14 / 13$ & 10 & -- & -- & 190 & Good & 2013 & Not reported to Web site \\
\hline $10 / 15 / 13$ & 8.8 & -- & -- & 160 & Good & 2013 & Not reported to Web site \\
\hline $10 / 16 / 13$ & 10 & -- & -- & 190 & Good & 2013 & Not reported to Web site \\
\hline $10 / 17 / 13$ & 95 & -- & -- & 2,400 & Poor & 2013 & Not reported to Web site \\
\hline $10 / 18 / 13$ & 38 & -- & -- & 850 & Poor & 2013 & Not reported to Web site \\
\hline $10 / 19 / 13$ & 20 & -- & -- & 410 & Poor & 2013 & Not reported to Web site \\
\hline $10 / 20 / 13$ & 26 & -- & -- & 550 & Poor & 2013 & Not reported to Web site \\
\hline $10 / 21 / 13$ & 15 & -- & -- & 300 & Poor & 2013 & Not reported to Web site \\
\hline $10 / 22 / 13$ & 16 & -- & -- & 320 & Poor & 2013 & \\
\hline $10 / 23 / 13$ & 13 & -- & -- & 250 & Good & 2013 & \\
\hline $10 / 24 / 13$ & 12 & -- & -- & 230 & Good & 2013 & \\
\hline $10 / 25 / 13$ & 11 & -- & -- & 210 & Good & 2013 & \\
\hline $10 / 26 / 13$ & 9.5 & -- & -- & 200 & Good & 2013 & \\
\hline $10 / 27 / 13$ & 10 & -- & -- & 190 & Good & 2013 & \\
\hline $10 / 28 / 13$ & 12 & -- & -- & 300 & Poor & 2013 & \\
\hline $10 / 29 / 13$ & 13 & -- & -- & 250 & Good & 2013 & \\
\hline $10 / 30 / 13$ & 13 & -- & -- & 250 & Good & 2013 & \\
\hline $10 / 31 / 13$ & 12 & -- & -- & 280 & Good & 2013 & \\
\hline $11 / 01 / 13$ & 110 & -- & -- & 3,600 & Poor & 2013 & \\
\hline $05 / 28 / 14$ & 120 & 13,000 & -- & 3,400 & Poor & 2014 & \\
\hline $05 / 29 / 14$ & 39 & -- & -- & 2,000 & Poor & 2014 & \\
\hline $05 / 30 / 14$ & 25 & -- & -- & 910 & Poor & 2014 & \\
\hline
\end{tabular}


Table 1-1. Nowcast predictions for the Cuyahoga River at Jaite sampling site in the Cuyahoga Valley National Park, 2012-14.—Continued

[Indicated in the notes are dates when the predicted water quality was not reported to the Ohio Nowcast Web site (http://www.ohionowcast.info/) due to issues with the Web site or scheduled run of the computer program used to update the Web site. Morning samples were generally collected prior to 9 a.m.; afternoon samples were collected after 12 p.m. NTRU, nephelometric turbidity ratio unit; FNU, formazin nephelometric unit; E. coli, Escherichia coli; --, no data available; CFU/100 $\mathrm{mL}$, colony-forming unit per 100 milliliters; MNP/100 mL, most-probable number per 100 milliliters]

\begin{tabular}{|c|c|c|c|c|c|c|c|}
\hline Date & $\begin{array}{c}\text { Observed } \\
\text { turbidity, } \\
\text { in NTRU (2012) } \\
\text { or FNU } \\
(2013,2014)\end{array}$ & $\begin{array}{c}\text { Morning } \\
\text { actual } E \text {. coli, } \\
\text { in CFU/100 mL } \\
\text { unless } \\
\text { otherwise noted }\end{array}$ & $\begin{array}{c}\text { Afternoon } \\
\text { actual } E \text {. coli, } \\
\text { in CFU/100 mL } \\
\text { unless } \\
\text { otherwise noted }\end{array}$ & $\begin{array}{l}\text { Predicted } \\
\text { E. coli, in } \\
\text { CFU/100 } \\
\text { mL }\end{array}$ & $\begin{array}{l}\text { Predicted } \\
\text { water } \\
\text { quality }^{1}\end{array}$ & $\begin{array}{c}\text { Nowcast } \\
\text { used }^{2}\end{array}$ & Notes \\
\hline $05 / 31 / 14$ & 16 & -- & -- & 360 & Poor & 2014 & \\
\hline $06 / 01 / 14$ & 13 & -- & -- & 280 & Good & 2014 & \\
\hline $06 / 02 / 14$ & 10 & 120 & -- & 210 & Good & 2014 & \\
\hline $06 / 03 / 14$ & 11 & 180 & -- & 230 & Good & 2014 & \\
\hline $06 / 04 / 14$ & 8.1 & -- & 230 & 280 & Good & 2014 & \\
\hline $06 / 05 / 14$ & 230 & -- & -- & 7,100 & Poor & 2014 & \\
\hline $06 / 06 / 14$ & 19 & -- & -- & 1,600 & Poor & 2014 & \\
\hline $06 / 07 / 14$ & 12 & -- & -- & 260 & Good & 2014 & \\
\hline 06/08/14 & 10 & -- & -- & 210 & Good & 2014 & \\
\hline $06 / 09 / 14$ & 140 & 6,200 & -- & 4,000 & Poor & 2014 & \\
\hline $06 / 10 / 14$ & 65 & 1,600 & -- & 5,500 & Poor & 2014 & \\
\hline $06 / 11 / 14$ & 37 & 530 & -- & 900 & Poor & 2014 & \\
\hline $06 / 12 / 14$ & 26 & -- & -- & 830 & Poor & 2014 & \\
\hline $06 / 13 / 14$ & 21 & -- & -- & 630 & Poor & 2014 & \\
\hline $06 / 14 / 14$ & 19 & -- & -- & 420 & Poor & 2014 & \\
\hline $06 / 15 / 14$ & 15 & -- & -- & 410 & Poor & 2014 & \\
\hline $06 / 16 / 14$ & 13 & 150 & -- & 280 & Good & 2014 & \\
\hline $06 / 17 / 14$ & 12 & 210 & -- & 300 & Poor & 2014 & \\
\hline $06 / 18 / 14$ & 220 & 3,300 & -- & 8,400 & Poor & 2014 & \\
\hline $06 / 19 / 14$ & 120 & -- & -- & 14,000 & Poor & 2014 & \\
\hline $06 / 20 / 14$ & 78 & -- & -- & 7,300 & Poor & 2014 & \\
\hline $06 / 21 / 14$ & 220 & -- & -- & 9,300 & Poor & 2014 & \\
\hline $06 / 22 / 14$ & 56 & -- & -- & 2,500 & Poor & 2014 & \\
\hline $06 / 23 / 14$ & 40 & 430 & 370 & 960 & Poor & 2014 & \\
\hline $06 / 24 / 14$ & 170 & 3,500 & 2,800 & 4,900 & Poor & 2014 & \\
\hline $06 / 25 / 14$ & 150 & 17,000 & 20,000 & 10,000 & Poor & 2014 & \\
\hline $06 / 26 / 14$ & 63 & -- & -- & 4,700 & Poor & 2014 & \\
\hline $06 / 27 / 14$ & 39 & -- & -- & 1,600 & Poor & 2014 & \\
\hline $06 / 28 / 14$ & 31 & -- & -- & 710 & Poor & 2014 & \\
\hline $06 / 29 / 14$ & 29 & -- & -- & 660 & Poor & 2014 & \\
\hline $06 / 30 / 14$ & 39 & 5,000 & 1,300 & 920 & Poor & 2014 & \\
\hline 07/01/14 & 25 & 240 & 120 & 770 & Poor & 2014 & \\
\hline $07 / 02 / 14$ & 310 & 2,200 & -- & 9,300 & Poor & 2014 & \\
\hline 07/03/14 & 330 & -- & -- & 16,000 & Poor & 2014 & \\
\hline $07 / 04 / 14$ & 30 & -- & -- & 1,300 & Poor & 2014 & \\
\hline $07 / 05 / 14$ & 22 & -- & -- & 630 & Poor & 2014 & \\
\hline 07/06/14 & 16 & -- & -- & 330 & Poor & 2014 & \\
\hline $07 / 07 / 14$ & 14 & 140 & 110 & 290 & Good & 2014 & \\
\hline 07/08/14 & 12 & -- & -- & 280 & Good & 2014 & \\
\hline
\end{tabular}


Table 1-1. Nowcast predictions for the Cuyahoga River at Jaite sampling site in the Cuyahoga Valley National Park, 2012-14.-Continued

[Indicated in the notes are dates when the predicted water quality was not reported to the Ohio Nowcast Web site (http://www.ohionowcast.info/) due to issues with the Web site or scheduled run of the computer program used to update the Web site. Morning samples were generally collected prior to 9 a.m.; afternoon samples were collected after 12 p.m. NTRU, nephelometric turbidity ratio unit; FNU, formazin nephelometric unit; E. coli, Escherichia coli; --, no data available; CFU/100 $\mathrm{mL}$, colony-forming unit per 100 milliliters; $\mathrm{MNP} / 100 \mathrm{~mL}$, most-probable number per 100 milliliters]

\begin{tabular}{|c|c|c|c|c|c|c|c|}
\hline Date & $\begin{array}{c}\text { Observed } \\
\text { turbidity, } \\
\text { in NTRU (2012) } \\
\text { or FNU } \\
(2013,2014)\end{array}$ & $\begin{array}{c}\text { Morning } \\
\text { actual } E \text {. coli, } \\
\text { in CFU/100 mL } \\
\text { unless } \\
\text { otherwise noted }\end{array}$ & $\begin{array}{c}\text { Afternoon } \\
\text { actual } E \text {. coli, } \\
\text { in CFU/100 mL } \\
\text { unless } \\
\text { otherwise noted }\end{array}$ & $\begin{array}{c}\text { Predicted } \\
\text { E. coli, in } \\
\text { CFU/100 } \\
\mathrm{mL}\end{array}$ & $\begin{array}{c}\text { Predicted } \\
\text { water } \\
\text { quality }^{1}\end{array}$ & $\begin{array}{c}\text { Nowcast } \\
\text { used }^{2}\end{array}$ & Notes \\
\hline 07/09/14 & 33 & 670 & -- & 1,000 & Poor & 2014 & \\
\hline $07 / 10 / 14$ & 18 & -- & -- & 560 & Poor & 2014 & \\
\hline $07 / 11 / 14$ & 12 & -- & -- & 290 & Good & 2014 & \\
\hline $07 / 12 / 14$ & 9.9 & -- & -- & 190 & Good & 2014 & \\
\hline $07 / 13 / 14$ & 15 & -- & -- & 310 & Poor & 2014 & \\
\hline $07 / 14 / 14$ & 21 & -- & -- & 610 & Poor & 2014 & \\
\hline $07 / 15 / 14$ & 550 & 59,000 & -- & 28,000 & Poor & 2014 & \\
\hline $07 / 16 / 14$ & 38 & 1,900 & -- & 2,400 & Poor & 2014 & \\
\hline $07 / 17 / 14$ & 25 & 600 & -- & 540 & Poor & 2014 & \\
\hline $07 / 18 / 14$ & 23 & -- & -- & 490 & Poor & 2014 & \\
\hline $07 / 19 / 14$ & 20 & -- & -- & 420 & Poor & 2014 & \\
\hline $07 / 20 / 14$ & 26 & -- & -- & 1,200 & Poor & 2014 & \\
\hline $07 / 21 / 14$ & 17 & 210 & -- & 710 & Poor & 2014 & \\
\hline $07 / 22 / 14$ & 14 & 200 & -- & 280 & Good & 2014 & \\
\hline $07 / 23 / 14$ & 10 & 150 & -- & 190 & Good & 2014 & \\
\hline $07 / 24 / 14$ & 11 & -- & -- & 240 & Good & 2014 & \\
\hline $07 / 25 / 14$ & 9.6 & -- & -- & 200 & Good & 2014 & \\
\hline $07 / 26 / 14$ & 8.7 & -- & -- & 160 & Good & 2014 & \\
\hline $07 / 27 / 14$ & 670 & -- & -- & 32,000 & Poor & 2014 & \\
\hline $07 / 28 / 14$ & 410 & 20,000 & -- & 41,000 & Poor & 2014 & \\
\hline $07 / 29 / 14$ & 63 & 2,000 & -- & 3,000 & Poor & 2014 & \\
\hline $07 / 30 / 14$ & 51 & 570 & -- & 1,800 & Poor & 2014 & \\
\hline $07 / 31 / 14$ & 600 & -- & -- & 18,000 & Poor & 2014 & \\
\hline 08/01/14 & 64 & -- & -- & 2,800 & Poor & 2014 & \\
\hline $08 / 02 / 14$ & 58 & -- & -- & 1,300 & Poor & 2014 & \\
\hline $08 / 03 / 14$ & 41 & -- & -- & 900 & Poor & 2014 & \\
\hline $08 / 04 / 14$ & 39 & 800 & -- & 1,700 & Poor & 2014 & \\
\hline $08 / 05 / 14$ & 34 & 220 & -- & 1,600 & Poor & 2014 & \\
\hline $08 / 06 / 14$ & 39 & 4,900 & -- & 850 & Poor & 2014 & \\
\hline 08/07/14 & 29 & -- & -- & 1,400 & Poor & 2014 & \\
\hline 08/08/14 & 25 & -- & -- & 510 & Poor & 2014 & \\
\hline 08/09/14 & 20 & -- & -- & 400 & Poor & 2014 & \\
\hline $08 / 10 / 14$ & 17 & -- & -- & 330 & Poor & 2014 & \\
\hline $08 / 11 / 14$ & 14 & -- & -- & 270 & Good & 2014 & \\
\hline $08 / 12 / 14$ & 950 & 59,000 & -- & 30,000 & Poor & 2014 & \\
\hline $08 / 13 / 14$ & 140 & 4,800 & -- & 15,000 & Poor & 2014 & \\
\hline $08 / 14 / 14$ & 69 & 930 & -- & 2,500 & Poor & 2014 & \\
\hline $08 / 15 / 14$ & 43 & -- & -- & 930 & Poor & 2014 & \\
\hline $08 / 16 / 14$ & 31 & -- & -- & 640 & Poor & 2014 & \\
\hline
\end{tabular}


Table 1-1. Nowcast predictions for the Cuyahoga River at Jaite sampling site in the Cuyahoga Valley National Park, 2012-14.—Continued

[Indicated in the notes are dates when the predicted water quality was not reported to the Ohio Nowcast Web site (http://www.ohionowcast.info/) due to issues with the Web site or scheduled run of the computer program used to update the Web site. Morning samples were generally collected prior to 9 a.m.; afternoon samples were collected after 12 p.m. NTRU, nephelometric turbidity ratio unit; FNU, formazin nephelometric unit; E. coli, Escherichia coli; --, no data available; CFU/100 $\mathrm{mL}$, colony-forming unit per 100 milliliters; MNP/100 mL, most-probable number per 100 milliliters]

\begin{tabular}{|c|c|c|c|c|c|c|c|}
\hline Date & $\begin{array}{c}\text { Observed } \\
\text { turbidity, } \\
\text { in NTRU (2012) } \\
\text { or FNU } \\
(2013,2014)\end{array}$ & $\begin{array}{l}\text { Morning } \\
\text { actual } E \text {. coli, } \\
\text { in CFU/100 mL } \\
\text { unless } \\
\text { otherwise noted }\end{array}$ & $\begin{array}{c}\text { Afternoon } \\
\text { actual } E \text {. coli, } \\
\text { in CFU/100 mL } \\
\text { unless } \\
\text { otherwise noted }\end{array}$ & $\begin{array}{c}\text { Predicted } \\
\text { E. coli, in } \\
\text { CFU/100 } \\
\text { mL }\end{array}$ & $\begin{array}{c}\text { Predicted } \\
\text { water } \\
\text { quality }^{1}\end{array}$ & $\begin{array}{c}\text { Nowcast } \\
\text { used }^{2}\end{array}$ & Notes \\
\hline $08 / 17 / 14$ & 38 & -- & -- & 810 & Poor & 2014 & \\
\hline 08/18/14 & 20 & -- & -- & 440 & Poor & 2014 & \\
\hline 08/19/14 & 17 & -- & -- & 430 & Poor & 2014 & \\
\hline $08 / 20 / 14$ & 900 & -- & -- & 28,000 & Poor & 2014 & \\
\hline $08 / 21 / 14$ & 110 & -- & -- & 20,000 & Poor & 2014 & \\
\hline $08 / 22 / 14$ & 64 & -- & -- & 6,900 & Poor & 2014 & \\
\hline $08 / 23 / 14$ & 45 & -- & -- & 1,100 & Poor & 2014 & \\
\hline $08 / 24 / 14$ & 39 & -- & -- & 1,100 & Poor & 2014 & \\
\hline $08 / 25 / 14$ & 33 & 220 & -- & 680 & Poor & 2014 & \\
\hline $08 / 26 / 14$ & 27 & 250 & -- & 540 & Poor & 2014 & \\
\hline 08/27/14 & 28 & 620 & -- & 560 & Poor & 2014 & \\
\hline $08 / 28 / 14$ & 29 & 200 & -- & 710 & Poor & 2014 & Not reported to Web site \\
\hline $09 / 02 / 14$ & 12 & 240 & -- & 210 & Good & 2014 & Not reported to Web site \\
\hline 09/03/14 & 12 & 220 & -- & 250 & Good & $\begin{array}{c}\text { 2014- } \\
\text { backup }^{3}\end{array}$ & Radar rainfall unavailable \\
\hline 09/04/14 & 9 & -- & -- & 170 & Good & $\begin{array}{c}\text { 2014- } \\
\text { backup }^{3}\end{array}$ & Radar rainfall unavailable \\
\hline 09/08/14 & 19 & -- & -- & 640 & Poor & 2014 & \\
\hline 09/09/14 & 16 & 140 & -- & 290 & Good & 2014 & Actual E. coli is in MPN $/ 100 \mathrm{~mL}$ \\
\hline $09 / 10 / 14$ & 16 & -- & -- & 290 & Good & 2014 & \\
\hline 09/11/14 & 490 & -- & -- & 13,000 & Poor & 2014 & \\
\hline $09 / 12 / 14$ & 65 & -- & -- & 4,300 & Poor & 2014 & \\
\hline 09/13/14 & 38 & -- & -- & 930 & Poor & 2014 & \\
\hline $09 / 14 / 14$ & 25 & -- & -- & 530 & Poor & 2014 & \\
\hline $09 / 15 / 14$ & 22 & 150 & -- & 460 & Poor & 2014 & Actual E. coli is in MPN $/ 100 \mathrm{~mL}$ \\
\hline $09 / 16 / 14$ & 32 & 580 & -- & 620 & Poor & 2014 & Actual E. coli is in MPN $/ 100 \mathrm{~mL}$ \\
\hline 09/17/14 & 18 & -- & -- & 590 & Poor & 2014 & \\
\hline $09 / 18 / 14$ & 17 & -- & -- & 310 & Poor & 2014 & \\
\hline 09/19/14 & 15 & -- & -- & 270 & Good & 2014 & \\
\hline $09 / 20 / 14$ & 13 & -- & -- & 230 & Good & 2014 & \\
\hline $09 / 21 / 14$ & 11 & -- & -- & 190 & Good & 2014 & \\
\hline $09 / 22 / 14$ & 14 & 330 & -- & 300 & Poor & 2014 & Actual $E$. coli is in MPN $/ 100 \mathrm{~mL}$ \\
\hline $09 / 23 / 14$ & 10 & -- & -- & 220 & Good & 2014 & \\
\hline $09 / 24 / 14$ & 12 & -- & -- & 260 & Good & 2014 & \\
\hline $09 / 25 / 14$ & 9.2 & -- & -- & 150 & Good & 2014 & \\
\hline $09 / 26 / 14$ & 8.6 & -- & -- & 140 & Good & 2014 & \\
\hline $09 / 27 / 14$ & 8.3 & -- & -- & 160 & Good & 2014 & \\
\hline $09 / 28 / 14$ & 8.1 & -- & -- & 130 & Good & 2014 & \\
\hline 09/29/14 & 8.1 & -- & -- & 130 & Good & 2014 & \\
\hline
\end{tabular}


Table 1-1. Nowcast predictions for the Cuyahoga River at Jaite sampling site in the Cuyahoga Valley National Park, 2012-14.—Continued

[Indicated in the notes are dates when the predicted water quality was not reported to the Ohio Nowcast Web site (http://www.ohionowcast.info/) due to issues with the Web site or scheduled run of the computer program used to update the Web site. Morning samples were generally collected prior to 9 a.m.; afternoon samples were collected after 12 p.m. NTRU, nephelometric turbidity ratio unit; FNU, formazin nephelometric unit; E. coli, Escherichia coli; --, no data available; CFU/100 $\mathrm{mL}$, colony-forming unit per 100 milliliters; $\mathrm{MNP} / 100 \mathrm{~mL}$, most-probable number per 100 milliliters]

\begin{tabular}{|c|c|c|c|c|c|c|c|}
\hline Date & $\begin{array}{c}\text { Observed } \\
\text { turbidity, } \\
\text { in NTRU (2012) } \\
\text { or FNU } \\
(2013,2014)\end{array}$ & $\begin{array}{c}\text { Morning } \\
\text { actual } E \text {. coli, } \\
\text { in CFU/100 mL } \\
\text { unless } \\
\text { otherwise noted }\end{array}$ & $\begin{array}{c}\text { Afternoon } \\
\text { actual } E \text {. coli, } \\
\text { in CFU/100 mL } \\
\text { unless } \\
\text { otherwise noted }\end{array}$ & $\begin{array}{c}\text { Predicted } \\
\text { E. coli, in } \\
\text { CFU/100 } \\
\mathrm{mL}\end{array}$ & $\begin{array}{c}\text { Predicted } \\
\text { water } \\
\text { quality }^{1}\end{array}$ & $\begin{array}{c}\text { Nowcast } \\
\text { used }^{2}\end{array}$ & Notes \\
\hline 09/30/14 & 8.5 & -- & -- & 140 & Good & 2014 & \\
\hline $10 / 01 / 14$ & 21 & -- & -- & 380 & Poor & 2014 & \\
\hline $10 / 02 / 14$ & 8 & -- & -- & 270 & Good & 2014 & \\
\hline $10 / 03 / 14$ & 7.2 & -- & -- & 110 & Good & 2014 & \\
\hline $10 / 04 / 14$ & 71 & -- & -- & 1,500 & Poor & 2014 & \\
\hline $10 / 05 / 14$ & 13 & -- & -- & 530 & Poor & 2014 & \\
\hline $10 / 06 / 14$ & 8.3 & -- & -- & 210 & Good & 2014 & \\
\hline $10 / 07 / 14$ & 12 & -- & -- & 280 & Good & 2014 & \\
\hline $10 / 08 / 14$ & 14 & -- & -- & 390 & Poor & 2014 & \\
\hline $10 / 09 / 14$ & 7.7 & -- & -- & 260 & Good & 2014 & \\
\hline $10 / 10 / 14$ & 7.4 & -- & -- & 110 & Good & 2014 & \\
\hline $10 / 11 / 14$ & 7.8 & -- & -- & 120 & Good & 2014 & \\
\hline $10 / 12 / 14$ & 7.5 & -- & -- & 130 & Good & 2014 & \\
\hline $10 / 13 / 14$ & 8.3 & -- & -- & 130 & Good & 2014 & \\
\hline $10 / 14 / 14$ & 7 & -- & -- & 110 & Good & 2014 & \\
\hline $10 / 15 / 14$ & 44 & -- & -- & 840 & Poor & 2014 & \\
\hline $10 / 16 / 14$ & 180 & -- & -- & 10,000 & Poor & 2014 & \\
\hline $10 / 17 / 14$ & 22 & -- & -- & 570 & Poor & 2014 & \\
\hline $10 / 18 / 14$ & 18 & -- & -- & 510 & Poor & 2014 & \\
\hline $10 / 19 / 14$ & 20 & -- & -- & 510 & Poor & 2014 & \\
\hline $10 / 20 / 14$ & 16 & -- & -- & 460 & Poor & 2014 & \\
\hline $10 / 21 / 14$ & 16 & -- & -- & 6,500 & Poor & $\begin{array}{c}\text { 2014- } \\
\text { backup }^{3}\end{array}$ & Radar rainfall unavailable \\
\hline $10 / 22 / 14$ & 45 & -- & -- & 2,100 & Poor & 2014 & \\
\hline $10 / 23 / 14$ & 26 & -- & -- & 1,000 & Poor & 2014 & \\
\hline $10 / 24 / 14$ & 19 & -- & -- & 320 & Poor & 2014 & \\
\hline $10 / 25 / 14$ & 18 & -- & -- & 300 & Poor & 2014 & \\
\hline $10 / 26 / 14$ & 16 & -- & -- & 260 & Good & 2014 & \\
\hline $10 / 27 / 14$ & 15 & -- & -- & 240 & Good & 2014 & \\
\hline $10 / 28 / 14$ & 15 & -- & -- & 240 & Good & 2014 & \\
\hline $10 / 29 / 14$ & 14 & -- & -- & 230 & Good & 2014 & \\
\hline $10 / 30 / 14$ & 11 & -- & -- & 210 & Good & 2014 & \\
\hline $10 / 31 / 14$ & 11 & -- & -- & 170 & Good & 2014 & \\
\hline $11 / 01 / 14$ & 13 & -- & -- & 210 & Good & 2014 & \\
\hline $11 / 02 / 14$ & 9.2 & -- & -- & 140 & Good & 2014 & \\
\hline $11 / 03 / 14$ & 8.7 & -- & -- & 130 & Good & 2014 & \\
\hline
\end{tabular}

${ }^{1}$ Predicted water quality is listed as "Good" or "Poor" if it is below or above (respectively) the Ohio single-sample water-quality standard for primary-contact recreation (298 CFU/100 $\mathrm{ml}$ of E. coli).

${ }^{2}$ The nowcast used refers to the year the nowcast was validated.

${ }^{3}$ The 2014-backup model was used when radar-indicated rainfall observations or in-stream turbidity measurements was not available to run the primary predictive model. 



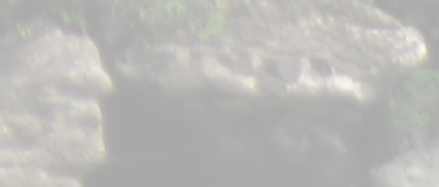

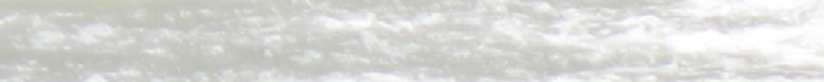

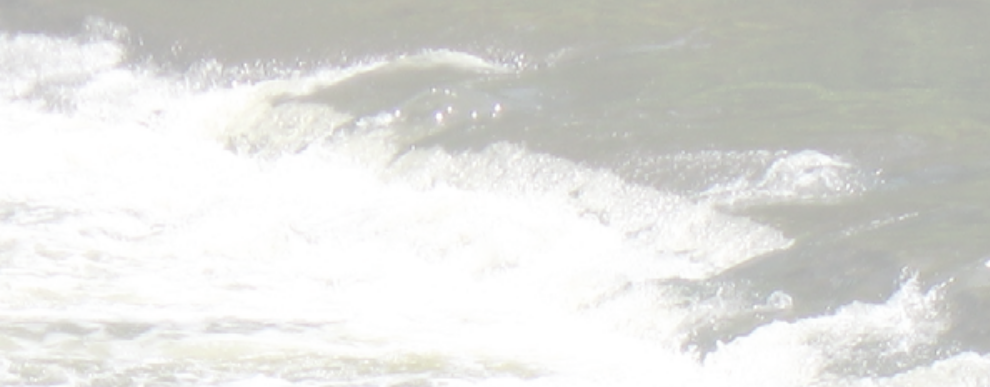

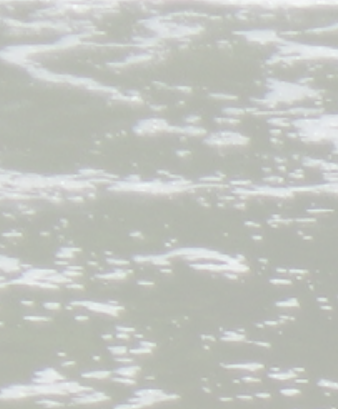

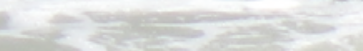

$\frac{y}{4}+5=0$
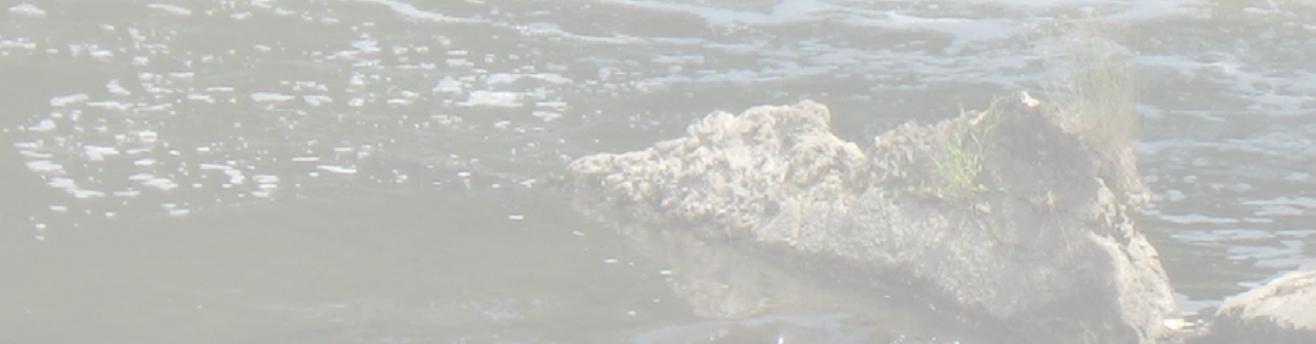

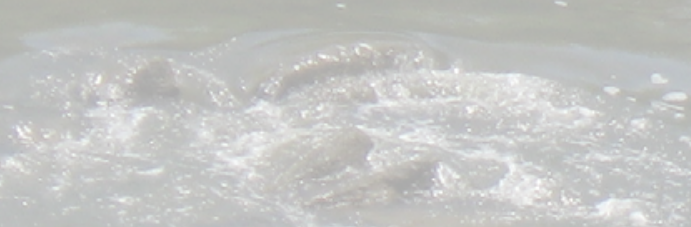

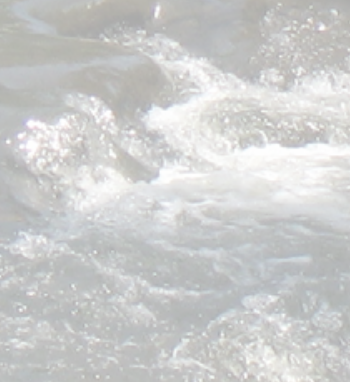

